\title{
New insights on structure and stratigraphic interpretation for assessing the hydrocarbon potentiality of the offshore Nile Delta basin, Egypt
}

\author{
Said Hanafy ${ }^{1} \cdot$ Shastri L. Nimmagadda ${ }^{2}$ - Sharaf Eldin Mahmoud ${ }^{3}$. \\ Walid M Mabrouk ${ }^{3}$
}

Received: 15 June 2015/Accepted: 3 June 2016/Published online: 16 June 2016

(c) The Author(s) 2016. This article is published with open access at Springerlink.com

\begin{abstract}
The study area lies around the petroleum provinces of the Egyptian Offshore Nile Delta basin. The existing exploration data are sparse, and any effort made on the strati-structural interpretation is challenging for exploratory drilling campaigns, even with meager well control. Keeping in view the issues and major challenges, the authors propose new methodologies, tools and new insights into the interpretation of the existing data and information, to make the study area more attractive for investors and detailed exploration studies. The published geological work existing within the vicinity of the study area is an added value to the new insights of current interpretation and knowledge acquisition. PliocenePleistocene section is the main target in the study area, since it has quality reservoirs, holding commercial hydrocarbons. Pre-salt source rocks may have charged the reservoirs in the study area. Structural complexities and heterogeneities at target levels are likely to impact the seismic wavelet property intricacies and thus the data processing qualities. Post- and pre-salt tectonics in the northern part of Sinai, the Nile Cone, and how they affect the structural framework and the seismic interpretation work in the study area are described. For the purpose of understanding the combinational trapping mechanism, stratigraphic features and the structural geology are
\end{abstract}

Shastri L. Nimmagadda

shastri.nimmagadda@curtin.edu.au

Said Hanafy

shanafy2002@yahoo.com

1 Tharwa Petroleum, Cairo, Egypt

2 School of Information Systems, CBS, Curtin University, Perth, WA, Australia

3 Department of Geophysics, Cairo University, Cairo, Egypt integrated using new tools and technologies. Several strati-structural plays are interpreted in the study area that support the detailed exploration campaigns, and the existing major hydrocarbon plays associated within shelf, slope and deep-marine geological events in nearby offshore regions. Diapir salt, rotated fault blocks and growth faults within syn-sediment systems are other plays to be investigated. The study is an effort of compiled work from many published sources, putting all ideas into a positive perspective and has better understanding of new opportunities, leads and prospects for investment purposes in the Nile Delta offshore basin.

Keywords Offshore Nile Delta basin - Structural and stratigraphic interpretation $\cdot$ New opportunities and leads

\section{Introduction}

The existing exploration work done in around the study area is briefly discussed. All the current literature is reviewed, exploring for new insights on the interpretation of the underexplored study area. The structure of north Sinai is one of the main attractive features of the Nile Delta geology in Egypt. Structural interpretation and sequence stratigraphy analysis have been done in nearby exploration areas (Dolson et al. 1996, 1997, 2000a, b). These studies provide fairly a broad structure framework of north Sinai, extrapolating and evidently extending this framework in the offshore part of the Nile Delta basin (Ayyad and Darwish 1996). The structure of north Sinai is the surface expression of the Sinai offshore subsurface structure, and it is extrapolated toward north with likely interference of the other structures and their associated fault orientations. The main structural feature in north Sinai is E-W- and SE-NW-

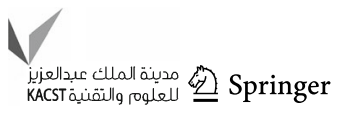


oriented asymmetric doubly plunging en-echelon anticlines bounded by SE-trending reverse fault with a gentle dip limp and intersected by normal and lateral movement fault systems. The limp closer to the main fault is short, steep dip and intersected by reverse faults. Though the anticlinal structure Gebel El Maghara has already been investigated (Moustafa and Khalil 1990; Bar-Yosef and Phillips 1977), its prospective is yet to be exploited. Hanafy et al. (2014) investigate the study area for new opportunities with new tools and technologies. New structure maps are intended to be computed in the study area using interactive interpretative workstations for the purpose of acquiring new geological knowledge.

\section{Problem statement and solutions}

The lack of tangible data and knowledge of the elements and processes of the petroleum systems within the study area are major constraints of the progressive and constructive exploration in the offshore Nile Delta region. Though proven systems are existing outside the study area, their presence is yet to be ascertained in the study area using the existing geological and geophysical knowledge. Possible pressure increases in the deeper part of the basin, and its likely effects on the hydrocarbon accumulations are other concerning issues. This type of study needs more data and different technology solutions. In addition, the velocity attribute issues associated with time-depth conversion affect the modeling process and thus the exploration prognosis analysis. For this reason, an experimental velocity model (to arrive at feasible seismic and depth models) is needed to initially analyze different potential effects of the salt layers, their thicknesses and velocities, especially the targeted layers in the deeper part of the basin. The proposed modeling study is envisioned to cover the entire Nile delta offshore basin, considering the existing structure and stratigraphic features of the region. As shown in Fig. 1, the study area is underexplored, in comparison with the Eastern (Gulf of Suez) and Western Desert basins. The rotated fault blocks, depositional environments, potential source, reservoir and seal rocks are intended to be interpreted in between Eastern and Western Desert basins, as illustrated in Fig. 1b. The problem solutions are summarized here:

1. Review of the existing general geologic setting of the Nile Delta, with particular emphasis on the Eastern sub-basin area.

2. Optimize the velocity function that can assist in modeling, fairly arriving at interpretable depth structures.
3. Integrate all the available exploration data incorporating the existing information on the structural framework and tectonics.

4. Compute new time and depth structure maps using latest workstation skills.

5. Interpret new structure maps and their trapping styles with varying extents.

6. Define and recommend the best location for drilling a successful exploratory well, based on the sound geological interpretation and logical conclusion.

\section{Database and methodology}

The available seismic data in the study area comprise of 65 2D seismic lines shot by different contractors and vintages. The recent exploration activity is that concession owner has drilled five wells targeting the Pliocene DHI anomalies. 3D seismic data were also acquired based on which shallow NH-1, 2, 3, 4 and 6 wells are drilled as shown in Fig. 1b. In addition, old wells surrounding the concession area drilled by different companies are Flower-1, Hadeer-1, Fahd-1 and EDDM-1 well. These wells have penetrated different depths and formation targets. The data in the Mediterranean region are acquired using steamer technology, and the air gun is a seismic source. There are several producing oil and gas fields evaluated for commercial viability in the Plio-Pleistocene successions (Barsoum 2002; Barsoum et al. 1998) of the Mediterranean basin margin areas, especially within the North African context. As demonstrated in Fig. 2, there has been much exploration activity around the study area with number of discoveries and number of productive wells drilled, suggesting the significance and expediting the exploratory efforts in the current study area.

Several geophysical methods of exploration and prospecting are discussed in Dobrin (1976) and Telford et al. (1990) with problem solutions associated with the structural interpretation in the continental basin margin areas. There are in total seven seismic horizons chosen in the study area for interpreting various structural styles and keeping in view the existing producing oil and gas fields in nearby study area. An integrated framework is designed, and for this purpose, seismic and existing drilled-well data (from nearby fields) are integrated. The geological horizons are calibrated in the seismic data using check-shot data of nearby wells, Flower-1, Hadeer1, Fahd-1 and EDDM-1. These wells and their associated seismic profiles are shown in Figs. 3 and 4. Several seismic structure maps in both time and depth are computed using the workstation tools to identify the potential areas of four-way structural closures (dip-strike attributes 


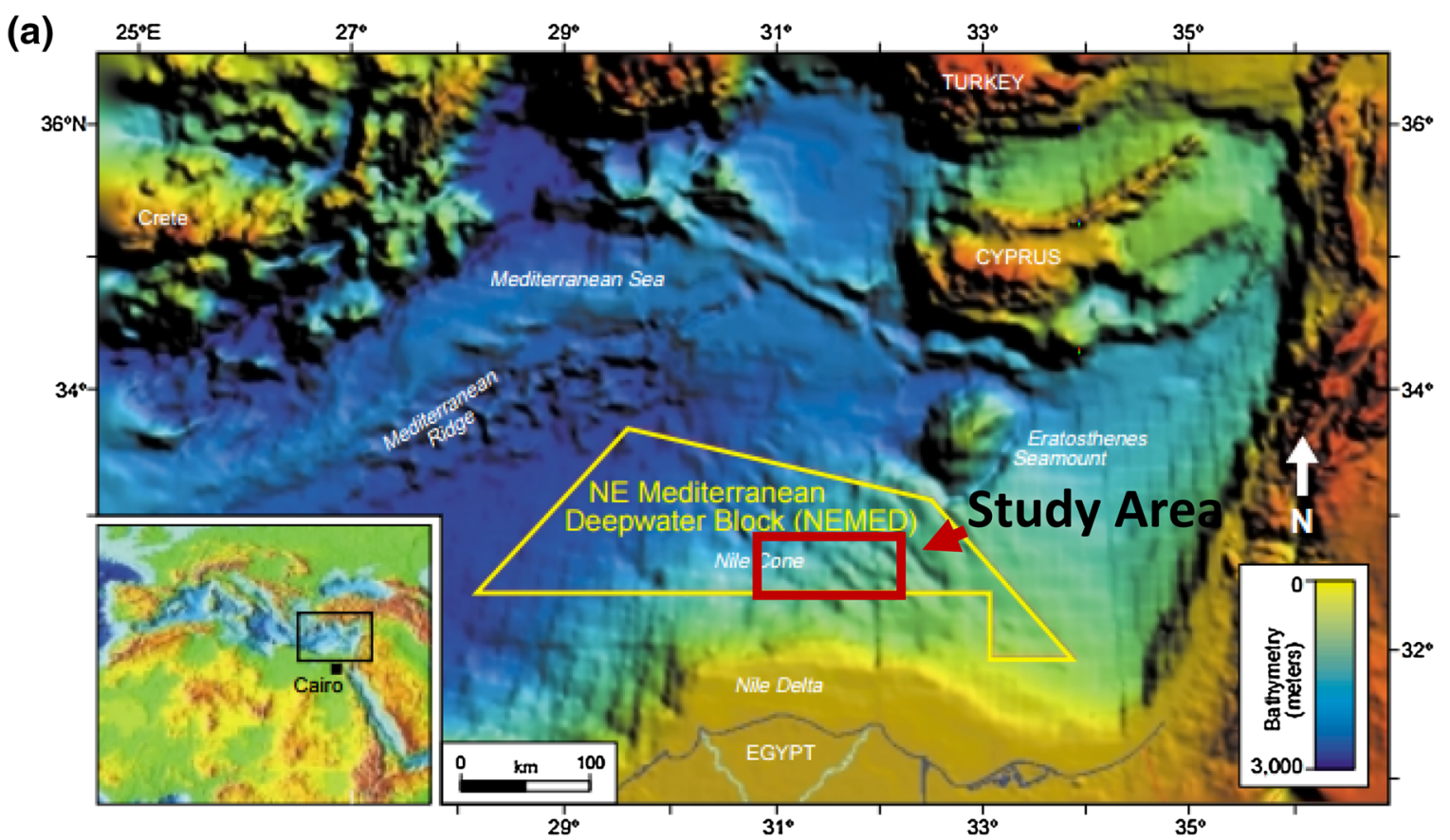

(b)

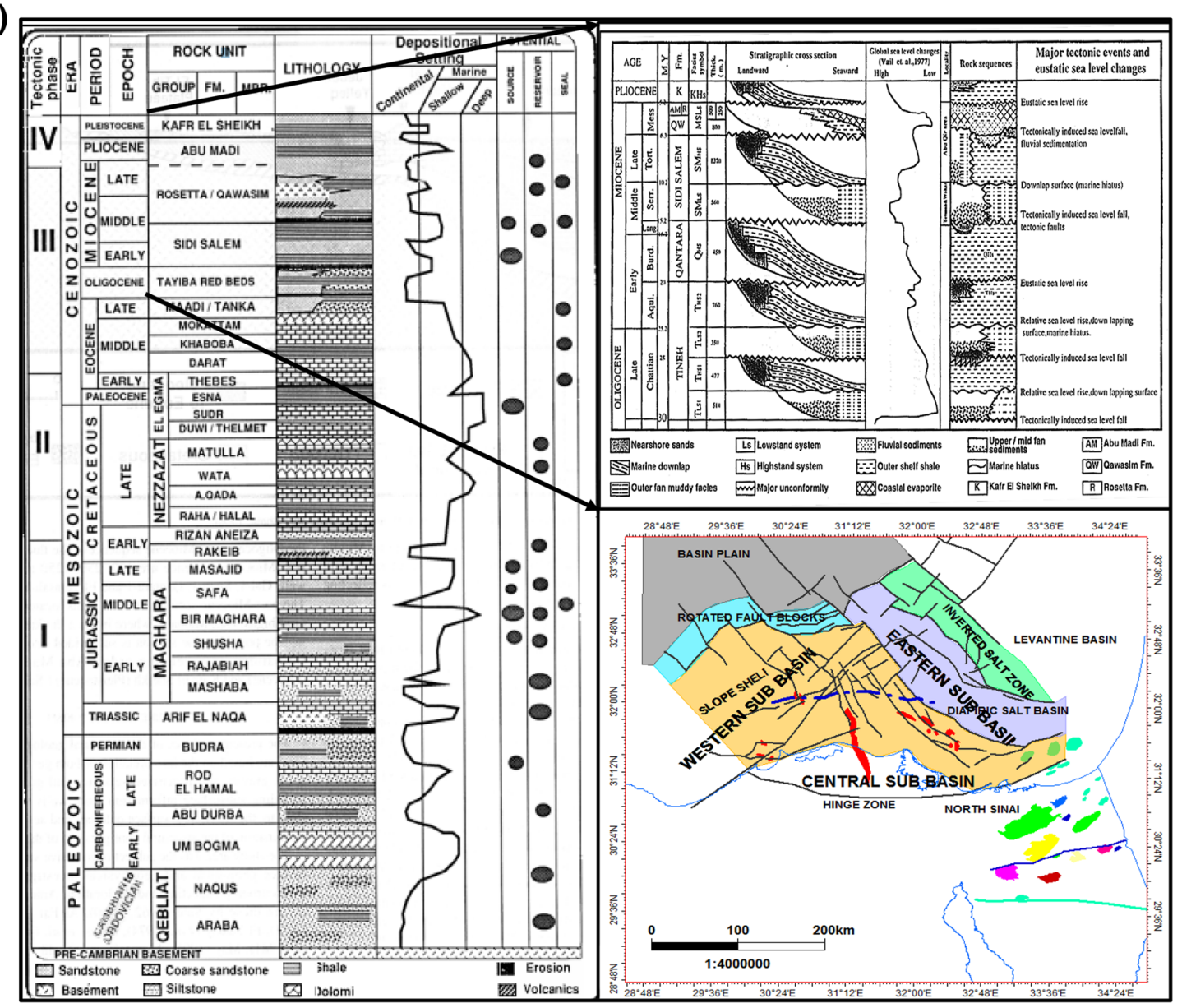

Fig. 1 a Regional geographic setting of the NE Mediterranean deepwater block (NEMED). b Generalized stratigraphy 
Fig. 2 Exploration status in and around the study area a discoveries $\mathbf{b}$ number of exploratory wells drilled in nearby basins
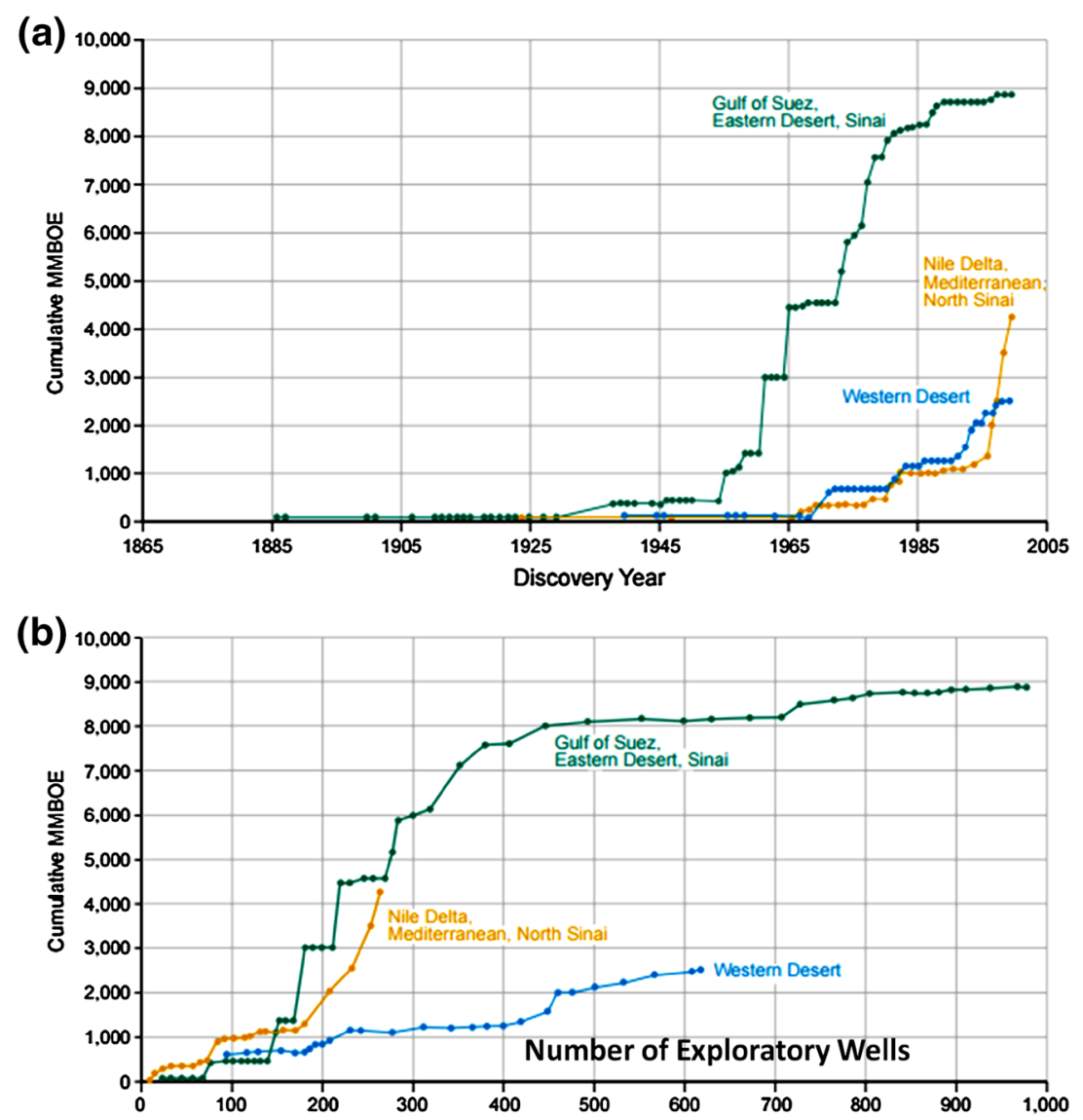

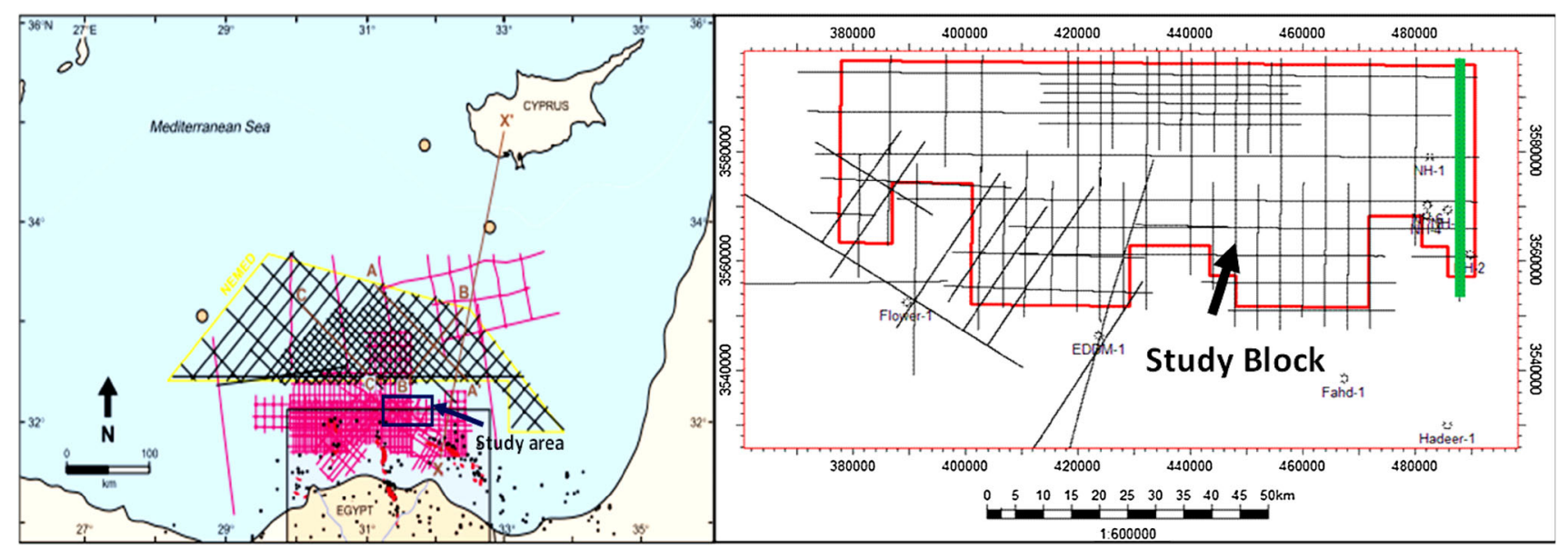

Fig. 3 Location map of the study area

associated with anticlinal closures). Time thickness maps are computed to ascertain the major salt thicknesses, paleo-structuring and possible sediment entries in the study area. Several DHI anomalies that attributed to stratigraphic features and geological characteristics of the drilled wells are integrated with their respective structure anomalies in the following sections.

\section{Review of the geological framework}

The structure of north Sinai is one of the main attractive features of the geological framework. NS-trending geological cross sections passing through the study area are presented in Fig. 5, describing various geological features such as, Messenian variations and sliding of Pleistocene 


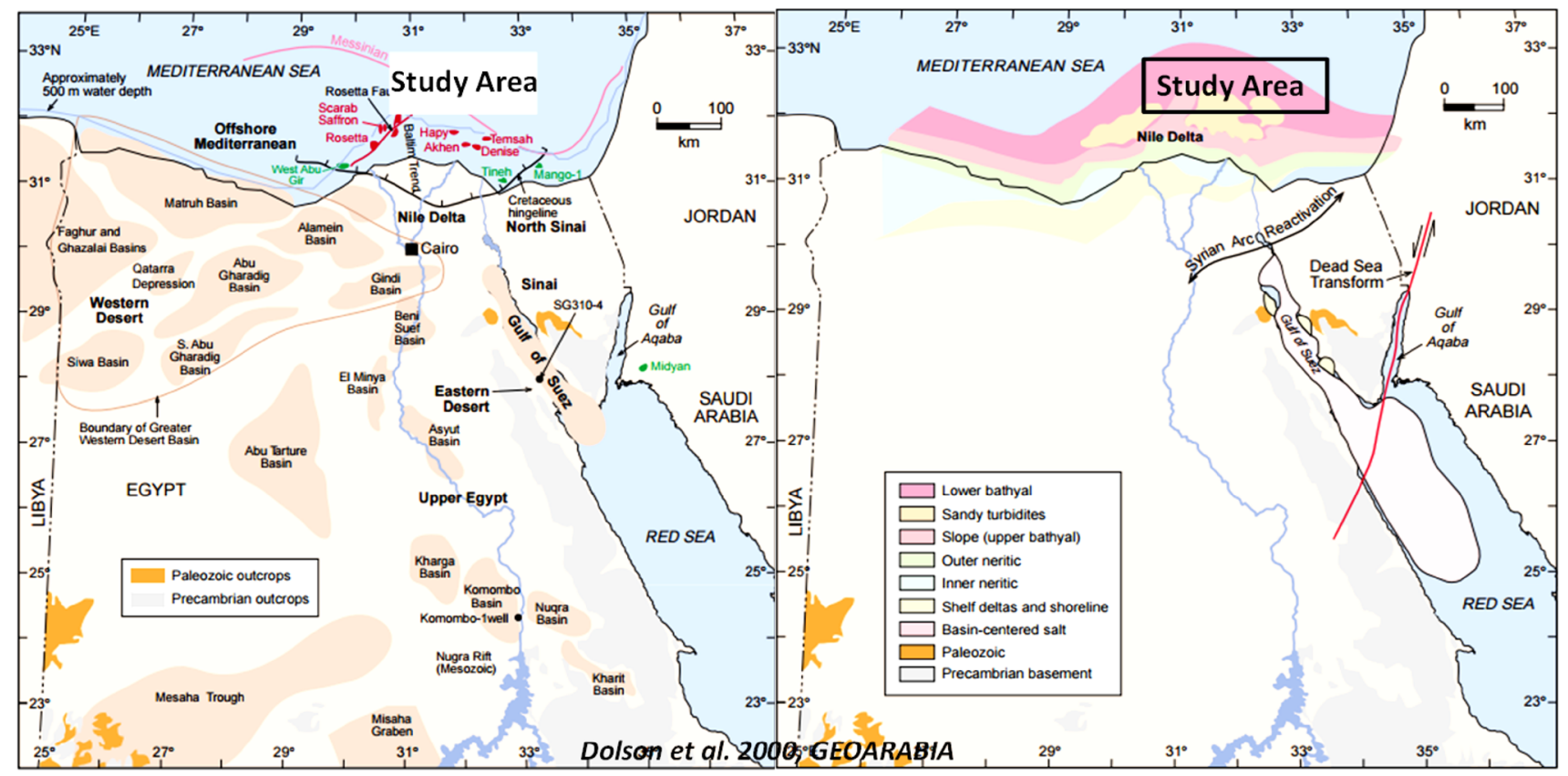

Fig. 4 Study area of the Nile Delta, western and eastern desert basins

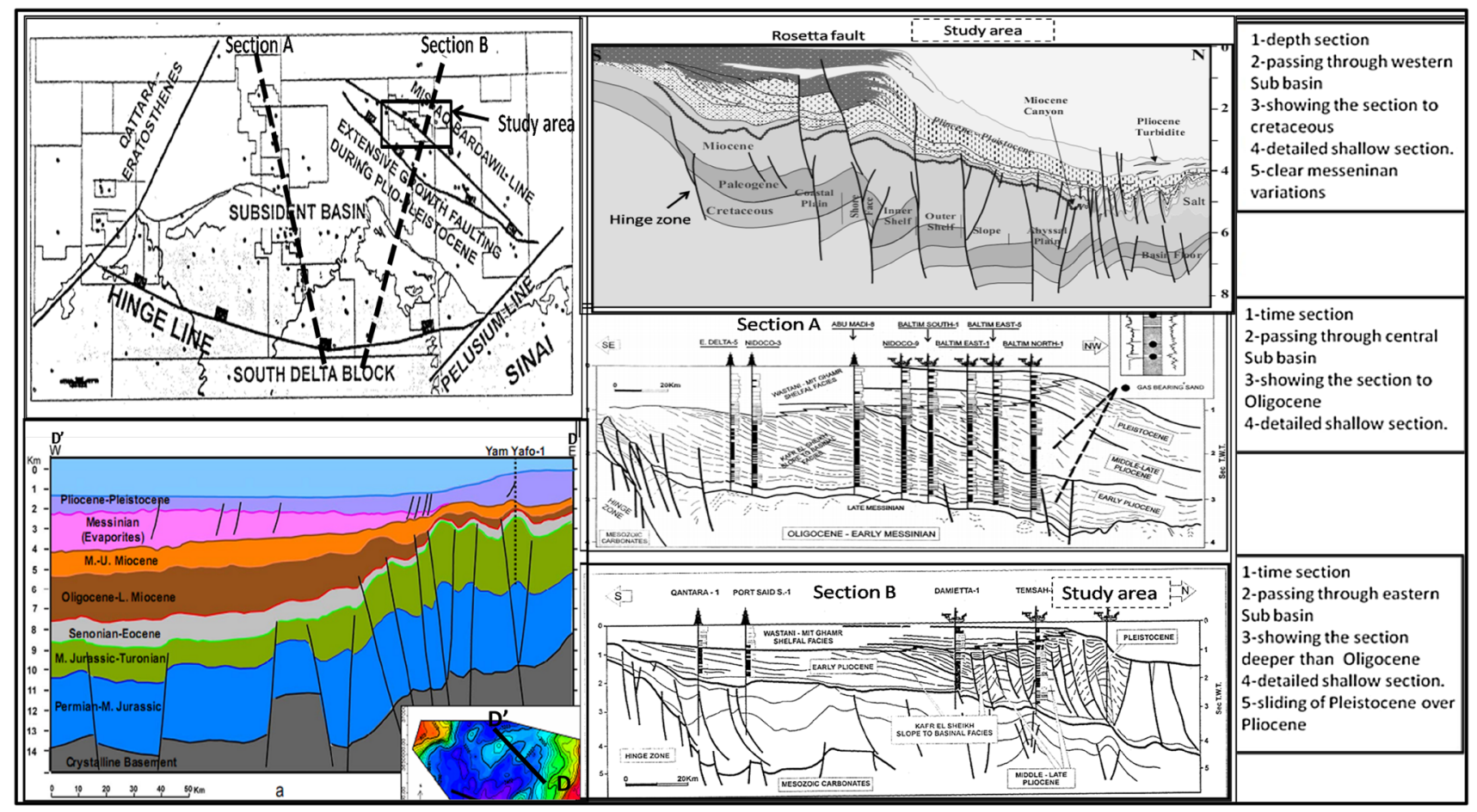

Fig. 5 Study area showing geological NS trend cross sections, $A$ and $B$

over Pliocene including growth faults, extensional and compressional fault features (Barsoum et al. 1998; Barsoum 2002; Magda 2002).

The belts interpreted from north to south are:

1. Gebel El Amrar belt.
2. Gebels El Torkmaniya, Um Mitmam and El Mistan belt.

3. Gebels El Urf, Um Latiya and El Mahash belt. Gebels Libni and Dalfa probably represent the east-northeast extension of this belt. 
4. Gebels Um Makhasa, Falig, Meneidret Abu Quroun, Meneidret El Etheili and south El Halal belt.

5. (a) Giddi Pass sub-belt, two other nearby sub-belts exist which are: (b) South Yelleq, El Minsherah subbelt; and (c) Gebels El Shereif, El Burqa and El Riash sub-belt.

6. (a) Mitla Pass sub-belt including Gebels Hamra, El Hamraa, Um Busal, Um Hreiba and another unnamed fold to the east of Gebel Um Hreiba. Gebel El Bruk is probably on the east-northeast end of this sub-belt. Two other nearby sub-belts exist which are: (b) Gebel Kherim sub-belt; and (c) Gebels Um Hosaira, Wasat El Baheiri and Araif El Naqa sub-belt.

The right stepping of the folds indicates that the strikeslip movement on the deep-seated faults was right lateral. Also the existence of thrusts in and between the en-echelon belt is indicative of block convergence, i.e., the strike-slip movement on the deep-seated faults is either convergent or transpressive (Lowell and Genik 1972). The northern part of Sinai is interpreted with east-northeast-oriented deepseated faults, whose origin seems to have been related to the opening of the Tethys due to the breakup of north Africa-Arabia in Late Triassic-Liassic periodic times (Biju-Duval et al. 1977, 1979; Argyriadis et al. 1980). The faults may have probably originated as northwest dipping normal faults in a passive continental margin.

Previous studies (Orwig 1982) suggest the existence of east- to east-northeast-oriented faults in the basement rocks of northern Egypt. They separate the craton (stable platform) area to the south from the structurally low area to the north, where sedimentary units abruptly increase their thicknesses (miogeosyncline). The distance between each of the northern five deep-seated faults is approximately $15 \mathrm{~km}$. On the other hand, the distance between the two southernmost faults is about one-half this value. The blocks lying between the deep-seated faults are also deformed by the right-lateral transpression. Therefore, Gebel El Maghara belongs to the deformed block lying between the second and third deep-seated faults. Gebel El Halal belongs to the deformed block between the third and fourth faults, and Gebel Yelleq belongs to the deformed block between the fourth and fifth faults. The axes of these three major structures and their accompanying thrusts make acute angles with the deep-seated faults. Generally, all the thrusts affecting these major mountain ranges dip northwestward. The steepness of southeastern trending structures perhaps represents the dragged leading edge of a thrust sheet or is probably draped over an underlying thrust fault similar to the Rocky Mountains structures (Abdel 1999; Abdel et al. 1996). As these positive structures popped up, the local extension parallel to their axes is affected. Therefore, the folded rocks develop transverse extension fractures with lateral dip-slip displacement. The E-W- to WNW-oriented right-lateral strike-slip faults dissecting the north Sinai structures represent one of the two conjugate sets of strikeslip faults that developed by the right-lateral wrenching. They are equivalent to the Riedel shears or the synthetic strike-slip faults (Biju-Duval et al. 1977; Wilcox et al. 2003). The set of strike-slip faults conjugate to Riedel shears has always little chance of its development (Tchalenko 1970) in the study area.

The area between the two southernmost deep-seated faults (fifth and sixth faults, after Abdel 1999; Abdel et al. 2001) is relatively narrow. Therefore, large structures similar to Gebels El Maghara, Yelleq and El Halal have not developed but settled with smaller folds instead. This area includes several diagonal-slip (right-lateral thrust) faults. During Late Cretaceous-Early Tertiary (Laramide) deformation, these preexisting deep-seated faults were rejuvenated by right-lateral transpression. Smith (1971) concludes this event as Atlantic spreading data since Africa moved west-northwest relative to Eurasia in Late Cretaceous to Late Eocene time. This motion could have produced a right-lateral shear, coupled in between North Africa and Eurasia. This shear couple has probably caused the right-lateral rejuvenation of the deep-seated faults in the northern Egypt. It is important to notice that the west-northwest-oriented shear couple makes an angle with the deep-seated faults which probably accounts for the convergent nature of the right-lateral wrenching. Study of the mesostructures in some of the north Sinai folds and similar ones in Palestine is in agreement with this conclusion. The maximum principle stress axis $(\sigma 1)$ that formed the mesostructures in the Cretaceous and Eocene rocks is oriented in $\mathrm{N} 287^{\circ} \pm 3^{\circ}$ (Eyal and Reches 1983). This stress direction probably accounts for the right-lateral convergent rejuvenation of the preexisting east-northeast-oriented deepseated faults of north Sinai.

The tectonic evolution of northern Sinai indicates that Late Triassic-Liassic rifting formed east to east-northeastoriented normal faults, which were reactivated during the closure of the Tethys by right-lateral transpression. Such structural inversion of old structures is probably similar to the deformation of the Atlas Mountains. The high and middle Atlas Mountains were formed by the inversion of an earlier Triassic rift structure in Late Cretaceous-Early Tertiary time (Stets and Wurster 1982). This deformation was related to the closure of the Tethys. Laubscher and Bernoulli (1977, 1978) examine the compressive movements of the Alpine systems that are accompanied by dextral movements. This adds further evidence to the rightlateral transpression in the northern Sinai, which was certainly related to the Alpine deformation.

The anticlinal structures associated with the Northern Sinai inverted Syrian arc system are extended in the offshore, and this is confirmed from drilling results of series of 
exploratory wells, such as Einab, Toffah, Mango and Golith. New exploration activities indicate the likely extension of these features in the study area, such as from the drilled well PFMD-1 in the southern part of the area, as shown in Fig. 6. The studies carried out on the Syrian arc system structures of North Sinai area are comprehensive, and details are comparable to the second promising trend or the NW transpressive movement fault system (Temsah, Bardawil). This fault is mainly active during Miocene age (Barsoum 2002; Barsoum 2002). Abdel et al. (2000a, b refer the likely occurrence of these faults as result of the inversion forces during the Late Cretaceous, and in this case they are parallel to the main trends (NW). These studies indicate the effect of faults' trend as it is observed in Fig. 6. The right-lateral movement of the northern eastern part of Sinai is comparable to the rest of the structure. These faults continue to exist in the north and intersect with NE fault trend in many places, thus forming the boundary of the eastern sub-basin, where all the Oligocene and Miocene producing fields exist as shown in Fig. 6 (After Hemdan and Barasi 2002). The resultant transpressive movement is a folded feature of nearly NWSE axis of Temsah gas field, as shown in Fig. 7 with deformation of old NNE-SSW-trending fold axis (Hemdan and Barasi 2002).

The offshore Nile Delta and the northern Sinai are subjected to different tectonic deformations (Abdel et al. 1994) in different geological times as shown in Fig. 8.

Syrian arc system is described with folded structures. Twofold systems of NE-SW and E-W fold axis of different amplitudes and sizes are generated during Late Cretaceous inversion. A system of NE-trending fold axis is generated as a result of Rosetta and Temsah transpressive movements, and affecting their deformations during Early Miocene or older and during Middle Miocene.

Nine fault trends (B fault systems) are recognized in the Mediterranean system (Fig. 8):

1. ENE-WSW left-lateral Pelusium mega-shear zone (pre-Cambrian).

2. E-W normal faults (Paleozoic).

3. NE-SW reverse faults (Late Cretaceous).

4. Arcuate normal fault zone (hinge zone Oligocene or older).

5. NE-SW right-lateral transpressive movement (Rosetta fault trend-Early Miocene).

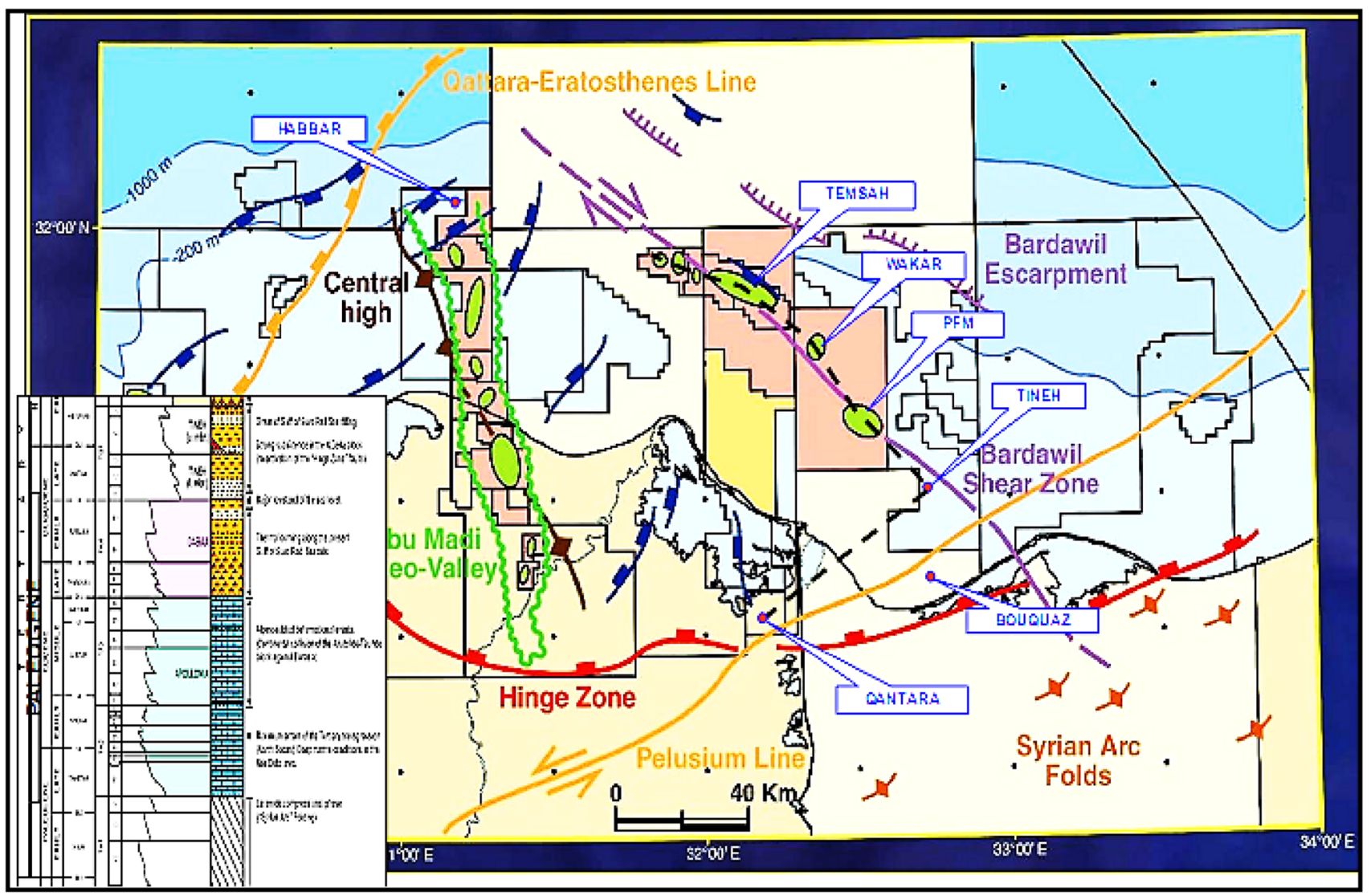

Fig. 6 Regional structural map of Nile Delta and gas-producing fields 


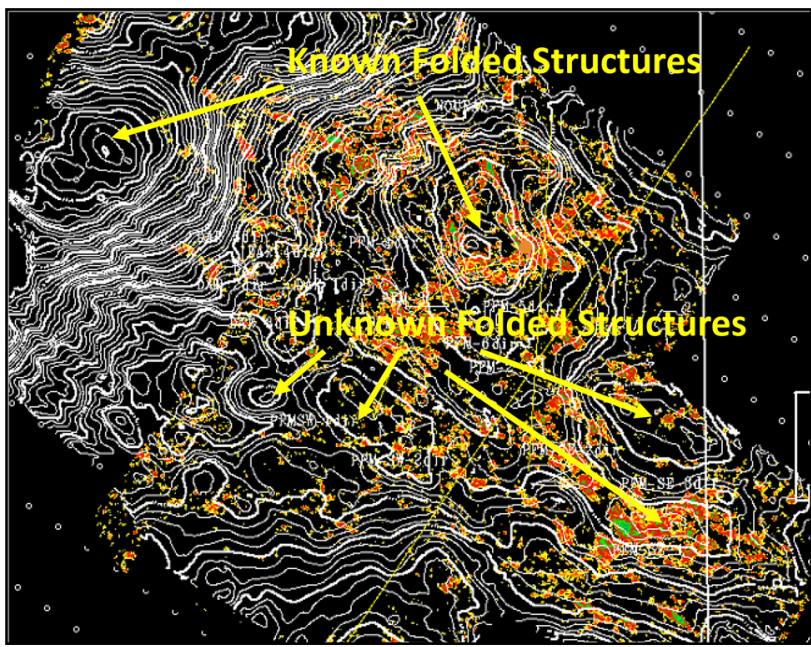

Fig. 7 PFM gas field, superimposition of depth and amplitude map on top of the Oligocene horizon

6. NW-SE right-lateral movement (Temsah trend-Middle Miocene).

7. NNW normal fault zone affecting mainly in the southern part (Clysmic trend-Eocene-Early Miocene).

8. NNE normal faults normal fault zone affecting mainly in the southern part (Aqaba trend-Miocene to present).

9. N-S Baltim normal fault trend (late Miocene).
According to structural setting and its regional trends, the Sinai Peninsula is subdivided into four provinces that are separated by three NNE-SSW- and ENE-WSWtrending major tectonic dislocation "shear zones" as shown in Fig. 7. Moustafa and Khalil (1990) recognize them less extended fold belts and name them as sub-belts. The major fold belts are:

A. Ragabet EI-Naam Shear Zone is named as Central Sinai Shear Zone. The most southern belt is probably a reactivated Paleozoic trend (Beyth 1981) as shown in Fig. 9. Dominance of E-W- and ENE-WSWtrending wrench faults and folds as interpreted in Abdel and Lelek (1994) are the result of pure shear forces. This shear zone separates the southern sector of the Sinai Peninsula, known as the stable shelf area (Said 1962), with its exposure on Precambrian basement in the transitional zone.

B. Minsherah-Abu Kandu Shear Zone separates the transitional zone, where both compressive and wrench stresses affected central Sinai, resulting flower structures along prominent right-lateral shear zones (Harding 1985). The unstable shelf in north Sinai is as shown in Fig. 8. Such flower structures have a remarkable thinning of the sedimentary section along the ENE-trending Jurassic wedge-edge, Gebel El- Minsherah (Abdel and Lelek 1994).

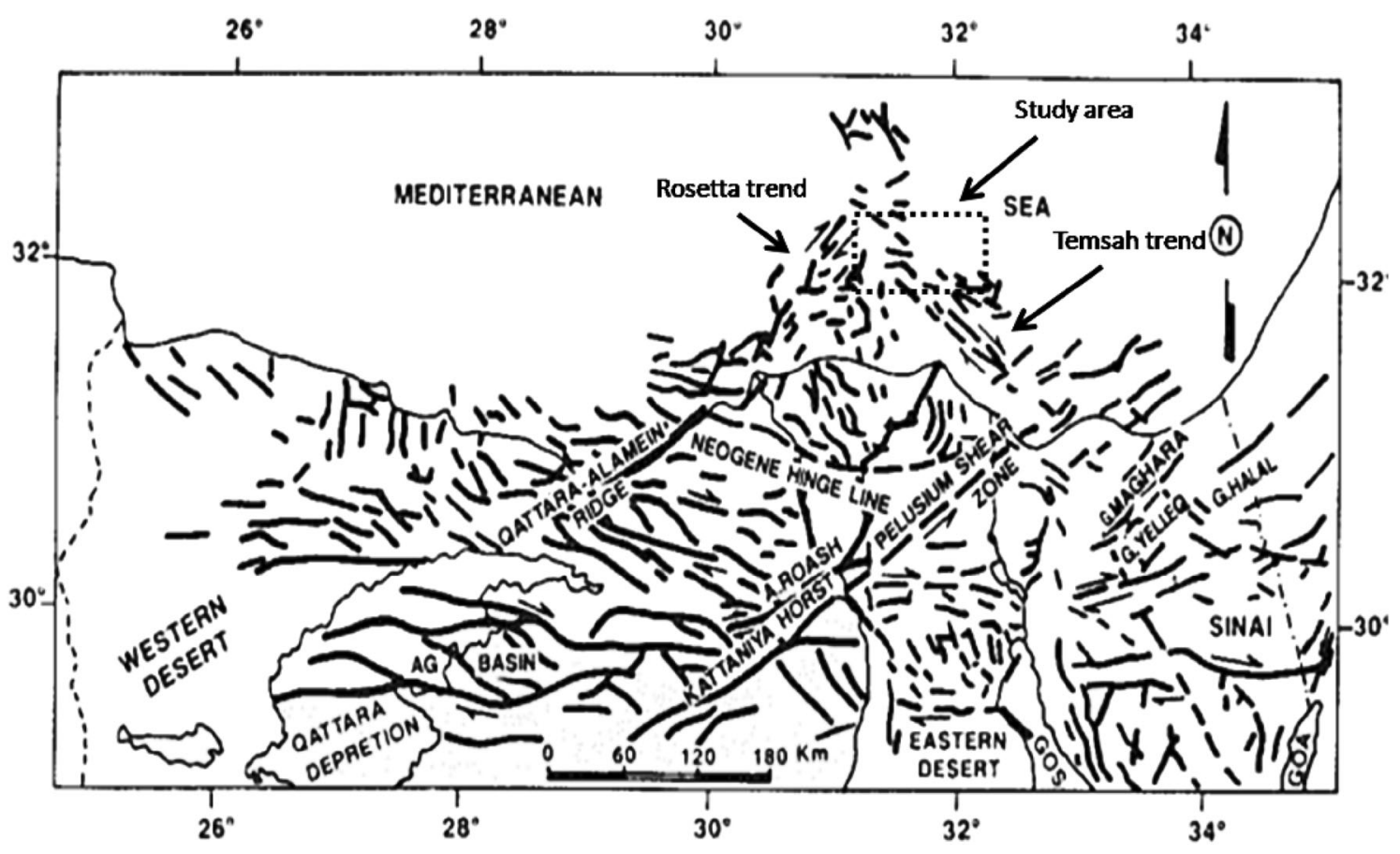

Fig. 8 Northern Egypt main tectonic elements 


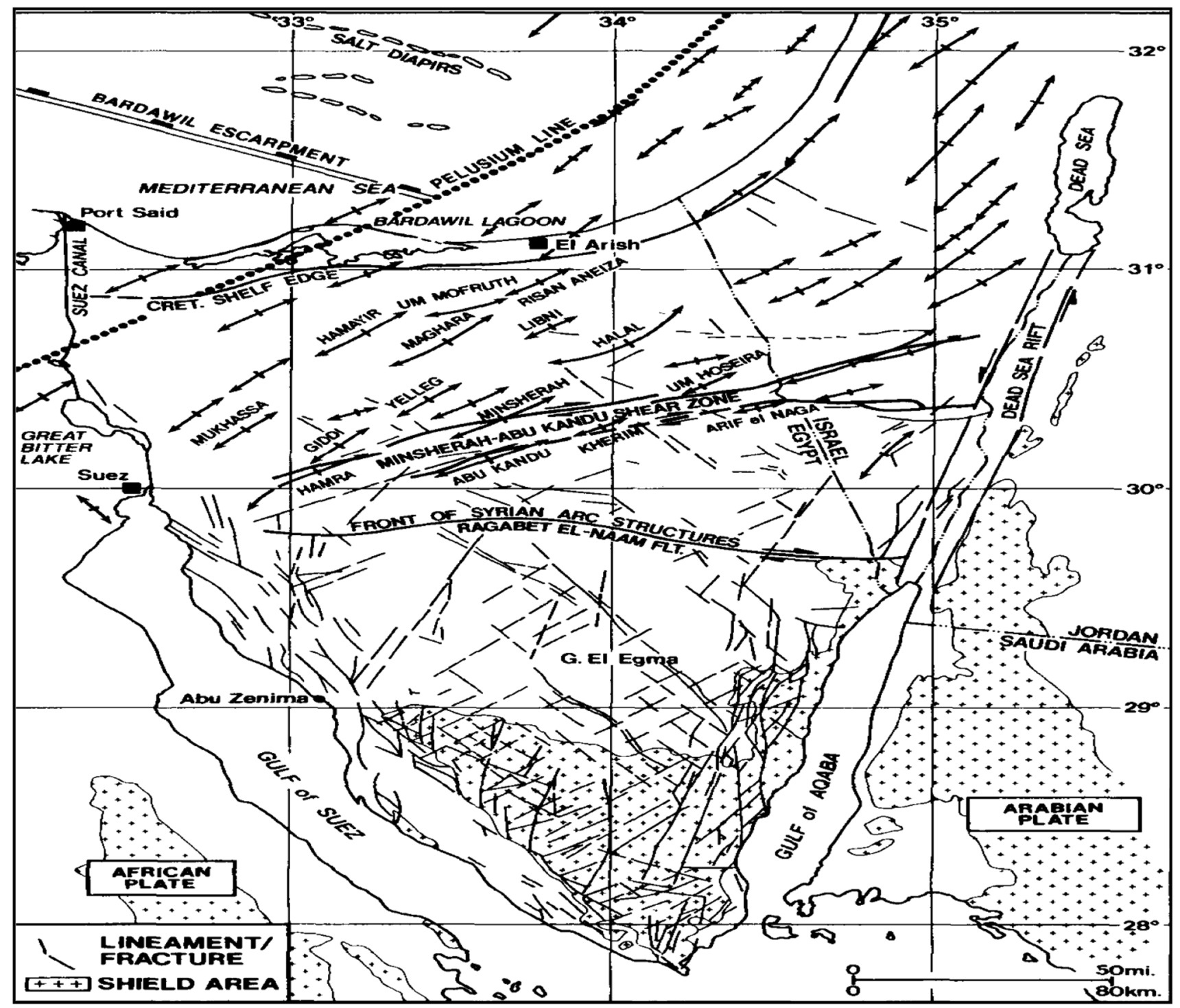

Fig. 9 Major tectonic elements in the northern Sinai district

C. Pelusium Shear Zone, as proposed by Neev (1975) and Neev et al. (1982), is a trend of NE-SW, and it isolates with the offshore structures that trending NE-SW from NW-SE, as shown in Fig. 9. This hinge zone truncates the Miocene Messinian evaporates, thus forming its southeastern boundary. Neev (1977) extrapolates the Pelusium line northwest of the Bardawil lagoon till the Western Desert, an onshore basin. Furthermore, it is outlined southwest through West Africa to the Atlantic Ocean, and hence, it is a transcontinental shear.

In the offshore part, there are two subzones. The Rosetta fault zone associated with the right-lateral movement and close to be Cretaceous time (Abdel et al. 1992) separates the central sub-basin from eastern sub-basin and makes the observable facies change, especially in Miocene-Oligocene formations. A right-lateral movement is interpreted with Temsah fault, which is close to the Cretaceous time or older (Abdel et al. 1992). This zone separates the eastern sub-basin from central sub-basin and forms a series of NW-SE folds in the eastern and central sub-basins.

\section{Major tectonic elements and history}

The Sinai Peninsula is bounded by major tectonic elements. These are the Mesozoic-Early Cenozoic tectonically active Tethys Sea to the north, the Oligo-Miocene Gulf of Suez rifted basin to the west, and the Late Miocene to recent transform Dead Sea-Gulf of Aqaba rift to the east. Each of these major elements has affected dramatically the 


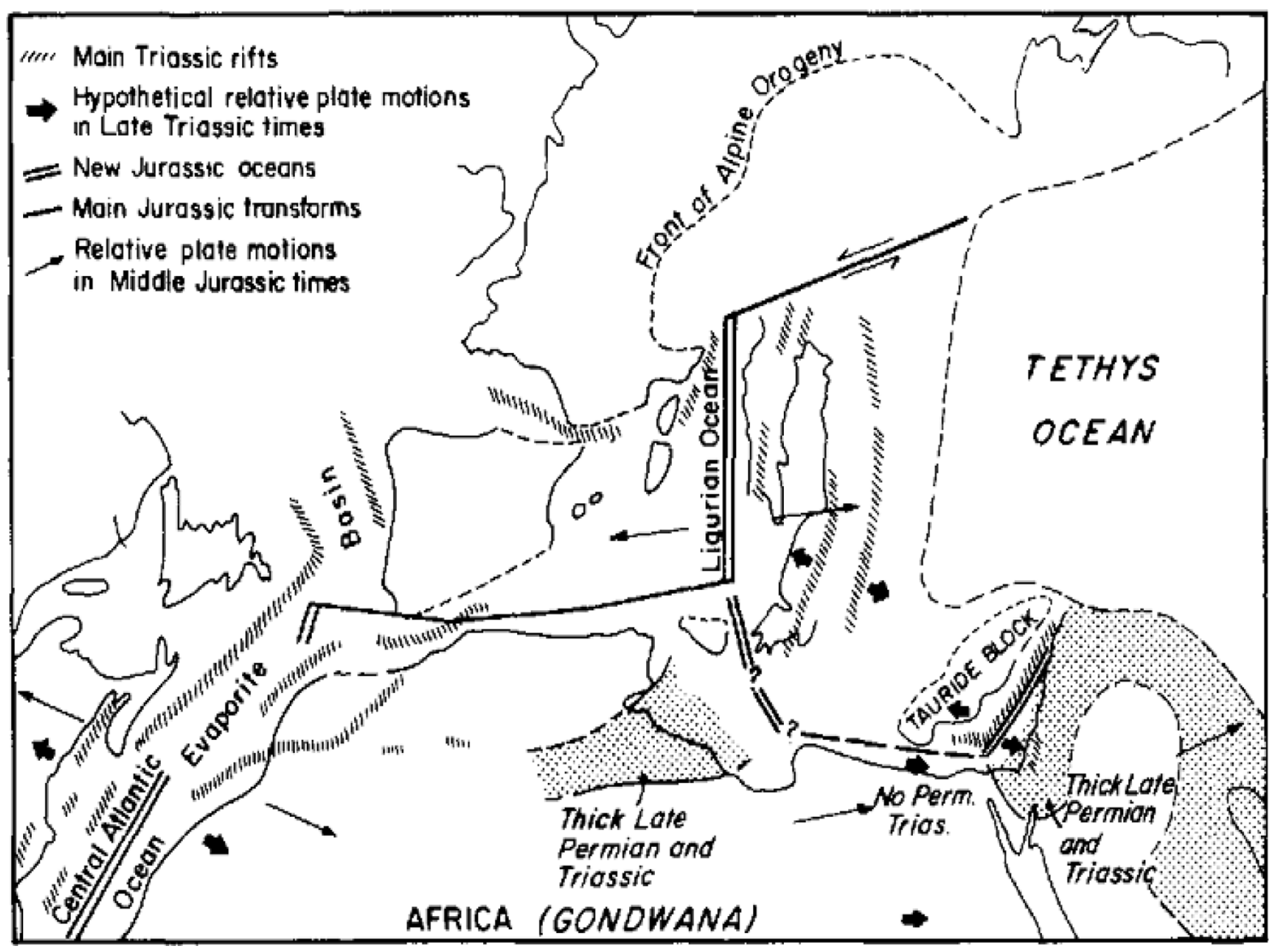

Fig. 10 Triassic and Jurassic rifting in the Tethys

structure and tectonic evolution of the northern Sinai area, which has again been subdivided into several tectonic phases as discussed in the following sections.

The Mesozoic through Tertiary tectonic history of northern Egypt has had a significant effect on the formation of the Nile Delta. The geological history of the northern Sinai is subdivided into three main phases:

During the first phase of Late Paleozoic to Early Mesozoic, a thick wedge of Early and Middle Mesozoic sediments was deposited. The southern edge of this sequence is north of a Late Paleozoic-Early Mesozoic E-W-trending fault zone, which bisects the Sinai Peninsula, (Abdel et al. 1992), and bounds the intra-cratonic Abu Gharadig basin in the central northwestern desert. Deep structures in the Nile Delta show that this hinge line bisected the delta parallel to preexisting E-W fault trend as shown in Figs. 8 and 9. During Triassic through Jurassic, left-lateral oblique-slip extension (Bernoulli and Lemoine 1980) is interpreted in the northern Egypt, as shown in Fig. 10. This was associated with the opening of the Tethys Sea as a result of the westward movement of Eurasia relative to Africa (Argyriadis et al. 1980). The main expressions of this movement are NE-SW- to ENE-WSW-trending faults in the northern Sinai and the Kattaniya horst in the east-central Western Desert. These faults are located parallel to the Pelusium mega-shear system (Neev et al. 1982), which extends along the eastern Mediterranean and across Africa through the Nile Delta as a system of en-echelon left-lateral faults active since Precambrian times. The NE-trending Rosetta fault trend is parallel to the Pelusium and the Jurassic NE- to ENE-trending fault lineaments along the extension of north Western Desert "Qantara-Alamein ridge." They are resultant to the right-lateral oblique-slip movement along the Rosetta fault trend during the Early Miocene.

The second tectonic phase was dominated by NW-SE oblique compression beginning in Early and Late Cretaceous (Turonian), culminating in latest Cretaceous (Laramide), and ending its affect in the Early Tertiary. This phase reflects the closing of the Tethys as a result of Eurasia moving southeast relative to Africa (Orwig 1982). This oblique compression produces a series of en-echelon NE-SW trending, doubly plunging anticlines (Syrian arc structures) in the northern Sinai and the Western Desert (Gebels Maghara, Halal and Yelleq in northern Sinai; Razzak, Alamein and Abu Roash structures in the Western Desert). This force also generates a series of NW to NNW extension faults, parallel to the major compressional stresses that affected the northern Egypt. The Temsah fault trend is located parallel to the NW lineament affecting the right-lateral oblique movement of the Middle Miocene age. 
The third tectonic phase extends from Eocene to Recent and is dominated by three tectonic trends. The first is the Late Eocene to Miocene Gulf of Suez trend. NNW-trending normal faults parallel with the Gulf of Suez rift are observed in the central Nile Delta. The second trend is related to the development of the Miocene to Recent Gulf of Aqaba rift, which was formed by left-lateral oblique-slip movement. Numerous examples of NNE fault trends are observed parallel to the Rosetta fault trend. The third trend developed in this phase is the NS Baltim structural fault trend, as well as the other previously discussed fault trends. It is thought that these trends are formed by rejuvenation and reactivating of older pre-Tertiary structures, during the Early Miocene.

\section{Structural restoration in the Nile Delta basin}

Rosetta fault is active during the entire period up to present day. NE-SW Rosetta fault trend shows a large-scale structural relief created by left-lateral transpressional movements until Late Miocene, starting from a preexisting (pre-Late Cretaceous) and inherited structural high. By Late Miocene, the structural relief evolved in transtension was covered by basinal sediments.

Misfaq-Bardawil (Temsah) fault appears to be active only since Miocene: The dominant fault movement is due to the pre-salt including post-salt reactivation. The evolution of the NW-SE Temsah fault trend is different in timing: even if the restoration of $2 \mathrm{D}$ sections crossing a strike-slip fault does not allow a correct balance, the thickness of the layers. The Oligocene setting shows the dextral wrench activity of the Temsah fault that began at Miocene age. The E-W-trending Nile Delta Hinge Zone consists of several northward-dipping normal faults, probably deeply rooted, bounding the southward-tilted half-graben fault blocks. The northward subsidence and sinking of the African margin in the Nile Delta area are mainly related to movements on the planes of these normal faults.

Two mechanisms are suggested for the deformation of the Nile Delta Hinge Zone: Fault block displacement along basement-rooted faults or northward gravitational sliding is allowed by listric faults and detachment/ décollment surfaces. Both these geological models describe the extensional tectonics in the south part of the studied area and could also be related to the compressional structures located against the Rosetta and Bardawil intersection. From a geometrical point of view, the restoration supports this relationship, evaluating the "volume" balance between the extensional displacement in the south (Hinge Zone) and the compression in the north (Cappelleti et al. 2010).

\section{Summary of the structural restoration and its interpretation}

Based on the tectonic history and structural framework, major geological features (EL Gamal and Mona 2010; Cappelleti et al. 2010) in the offshore Nile Delta are summarized (each section is illustrated in Fig. 11) here:

1. End of Cretaceous.

2. Emergence of Paleocene and the Eocene microcontinent.

3. Initiation of Mid Delta Oligocene rift and submerging of Paleo-Levant microcontinent and development of the Levant during the Early Oligocene with volcanic eruption.

4. Abortion of Mid Delta Oligocene rift with eruption of volcanic flow through Mit Ghamr shear, with a greater vertical motion on Oligo-Neogene hinge zone causing continental margin rifting.

5. High subsidence along the continental margin rift during the Early Miocene resulted in deposition of pelagic carbonates, hemipelagic shale and turbidities of Qantara formation.

6. Transgressive deposition of Serravallian and deposition of Sidi Salem formation.

7. Valley incision during the Tortonian.

8. Deposition of Qawasim formation.

9. Deposition of Early Messinian Evaporates, associated with further regression forces.

10. Deposition of Early Abu Madi formation, associated with further regression forces.

11. Deposition of Late Messinian Evaporates, associated with further drop in sea level.

12. Deposition of "Lago de Mar" during most Late Messinian due to forced transgression.

13. Deposition of Kafr El Shiekh formation during Early-mid Pliocene due to accelerated forced transgression, vertical motion and high rate of subsidence.

14. Deposition of the Late Pliocene El Wastani formation to the north of the Oligo-Neogene hinge zone.

15. Deposition of Pleistocene-Holocene formations.

\section{Computation and modeling the structure maps}

\section{Nomenclature of the horizons}

The available data do not include regional seismic lines that tied with deep wells. The horizons and ages are described in Table 1 and Fig. 12. The names are given for deeper horizons to facilitate the interpretation and analysis of the data. Some of the regional studies in the eastern Mediterranean are published with certain time names 


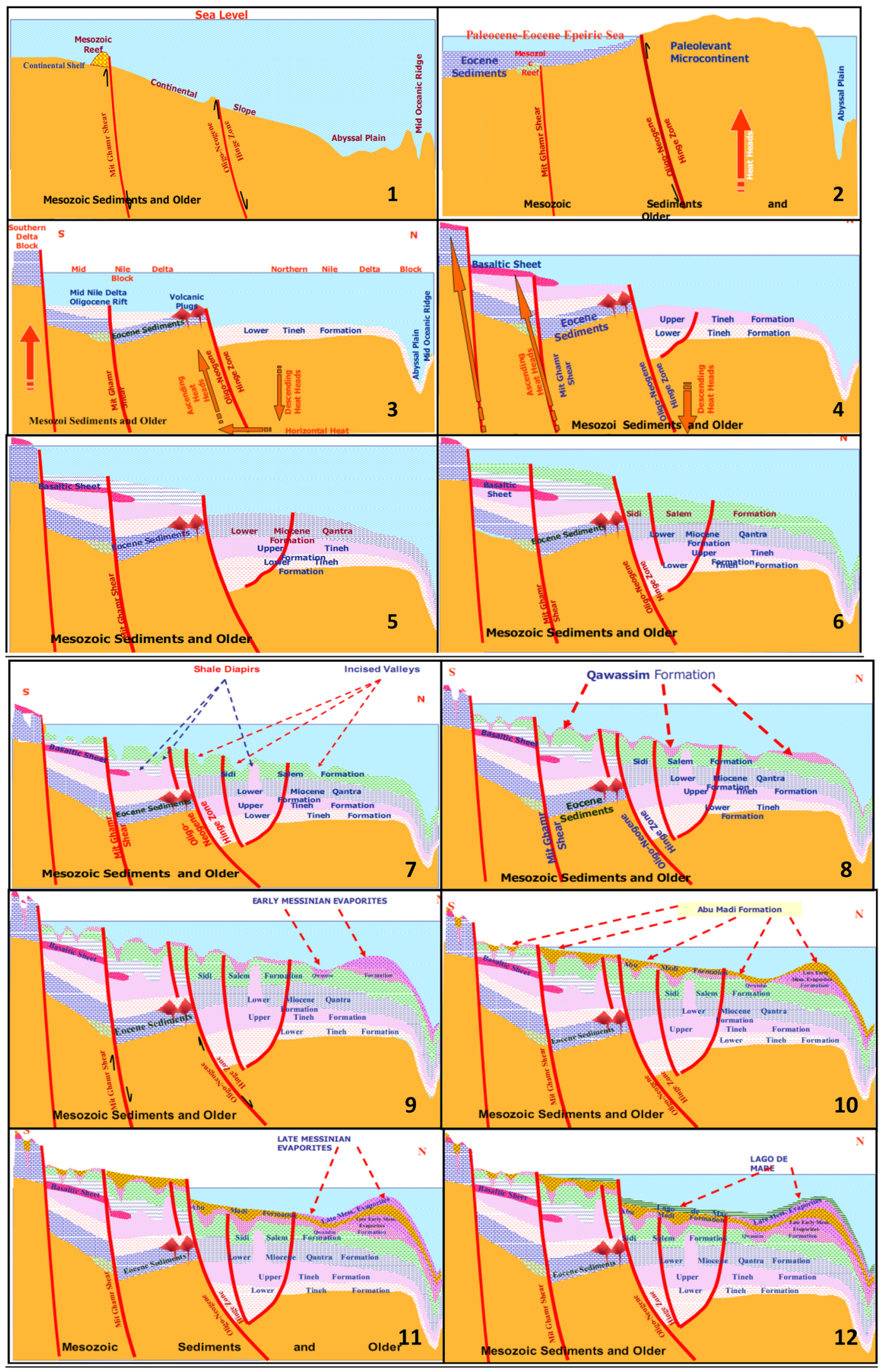

Fig. 11 Structure restoration features of the Nile Delta (1-15); distribution of Pliocene formation in the offshore Nile Delta region 


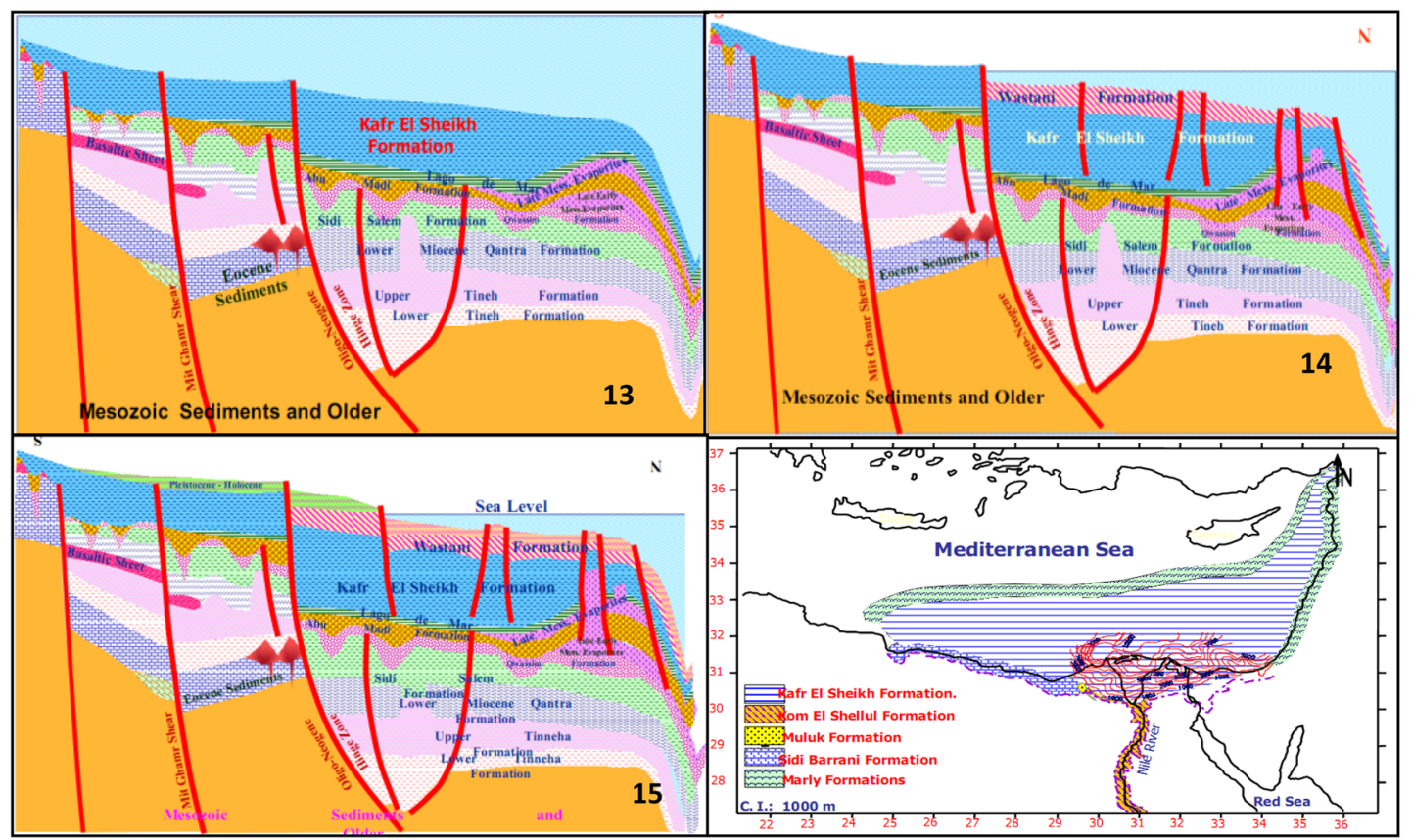

Fig. 11 continued

Table 1 Horizons and their age

\begin{tabular}{lll}
\hline This study & Nearby study & After correlation \\
\hline Pre-salt-1 & M.U. Miocene & Tortonian \\
Pre-salt-2 & & Intra-Serravallian \\
Oligocene & Oligocene-Miocene & Oligocene \\
Pre-salt-3 & Eocene-Cretaceous & Top carbonates \\
\hline
\end{tabular}

(Abdel et al. 2000a, b). These data are compared with the available data that provide a potential idea about the target horizons.

The rules used in horizons' selection are:

1. Understanding the geology of the area.

2. Likely zonation of the different geological and geophysical groups.

3. Potential leads in the area that supported by DHI features.

The time structures displayed in Fig. 13 suggest a general syncline-trending NNW-SSE direction. The geometries of these structural lows are irregular with anticlinal structural closures in between structure maps of sea bottom and top of the salt structures. Salt base shows terracing features within the major syncline area. Pre-salt- 1 and Presalt-2 show similar structural trends with subtle changes in the structural patterns. Oligocene structure shows interesting structural high closures in the western part of the study area, and they are trending SW-NE direction. Presalt-3 shows a different trend replicating the morphology of the Nile Cone.
As shown in Fig. 15, the depth of the drilled well starts after $1500 \mathrm{~m}$. For this reason, this method is used for layers below the salt. The first three surfaces, sea bottom, top salt and base salt are the same from layer cake without any conversion, especially with very small change from the default values of the surfaces. But for comparison, the equation is applied to all surfaces from top to bottom. The difference between two methods is calculated according to the equation: Difference = equation depth - layer cake depth.

Depth structures as shown in Fig. 15 have similar structural patterns and trends as that of time structures (Fig. 14). They are much smoother compared to the layer cake method of depth computations. Structures shown in Fig. 15 are not comparable with the patterns and trends of time structures in Fig. 14. Computing the structures through equation method appears resembling with the time structural patterns.

\section{Producing anomalies}

The deltaic and turbidite sandstones of Pliocene age are the current focus from traps of shelf and turbidite channels as shown in Figs. 16a, b and in Tables 2 and 3. Previous explorers and researchers (Abdel et al. 2000a, b) suggest 93.5 percent of Pliocene targets are successful. The authors interpret similar anomalies (Hanafy et al. 2014) in the study area (Fig. 17), which are potential structural traps associated with pre-salts or 


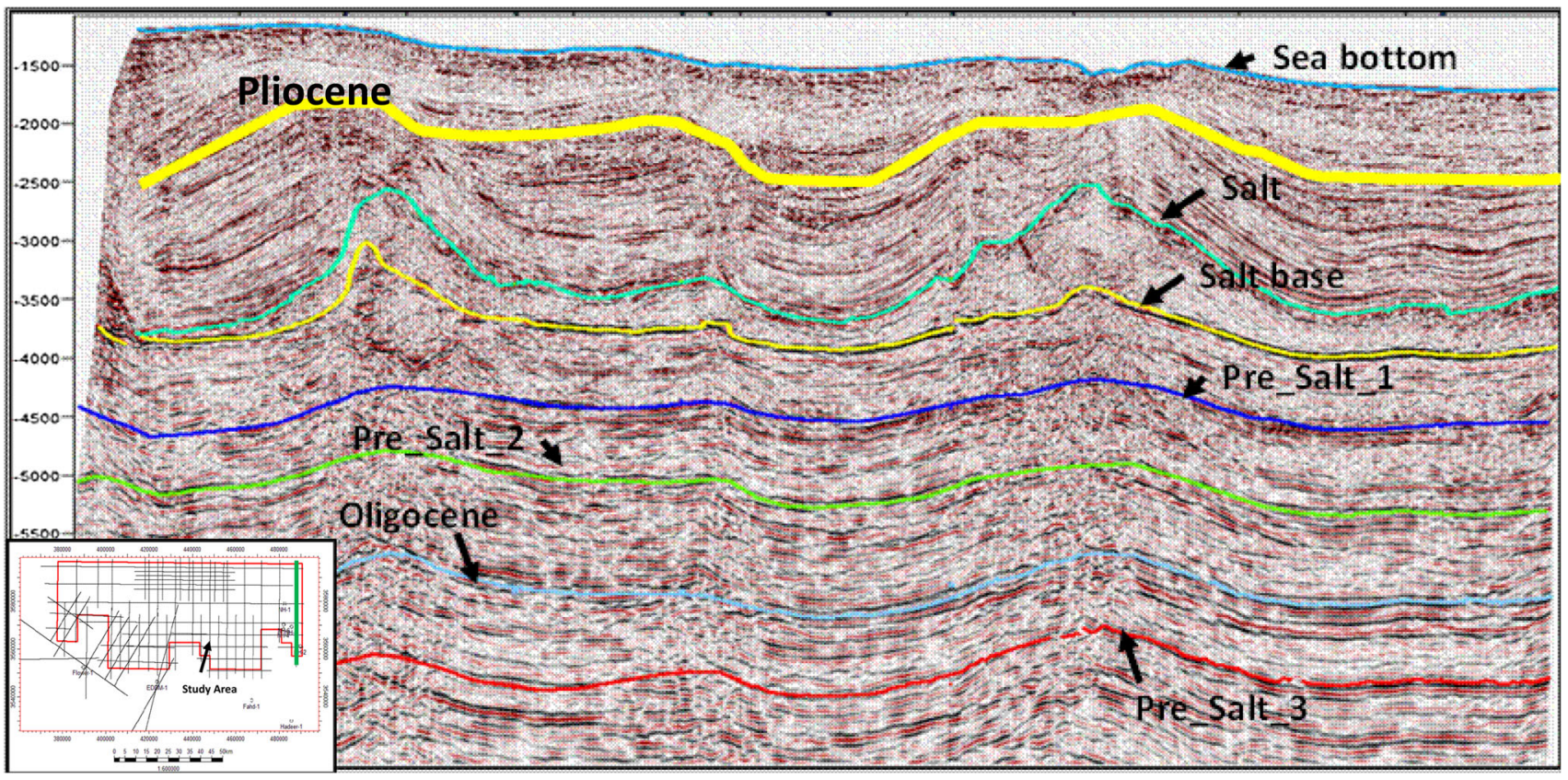

Fig. 12 Horizons chosen for interpretation and analysis in the study area

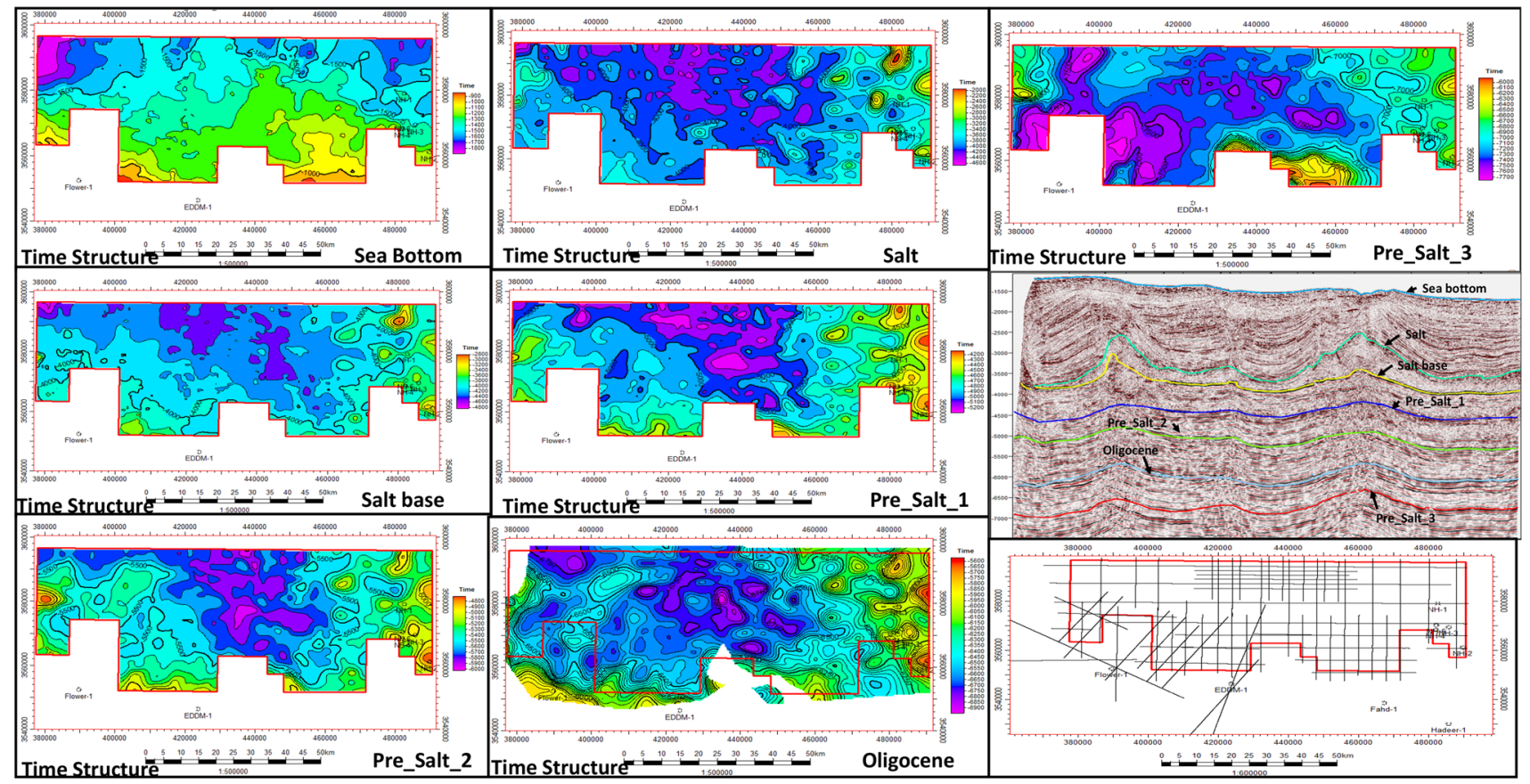

Fig. 13 Time structure maps computed for the horizons chosen in Fig. 12

strati-structural traps of Pliocene age sediments. Within the range of available exploration data, even in slope and deep-water settings, there is potential opportunity for structural and strati-structural traps. As described in Fig. 18, the sediment entries are expected from southerly direction and also thicker sediments are interpreted in the east-west directions.
The bright spots as observed in the seismic data in Fig. 17 are typically associated with direct hydrocarbon indicators, which are said to be stratigraphic traps, but not necessarily hydrocarbon bearing due to many reasons. One of them may be due to lithology-fluid, lithology-porosity, porosity-fluid and even lithology-lithology existence ambiguities in the investigating areas. In principle, they are 


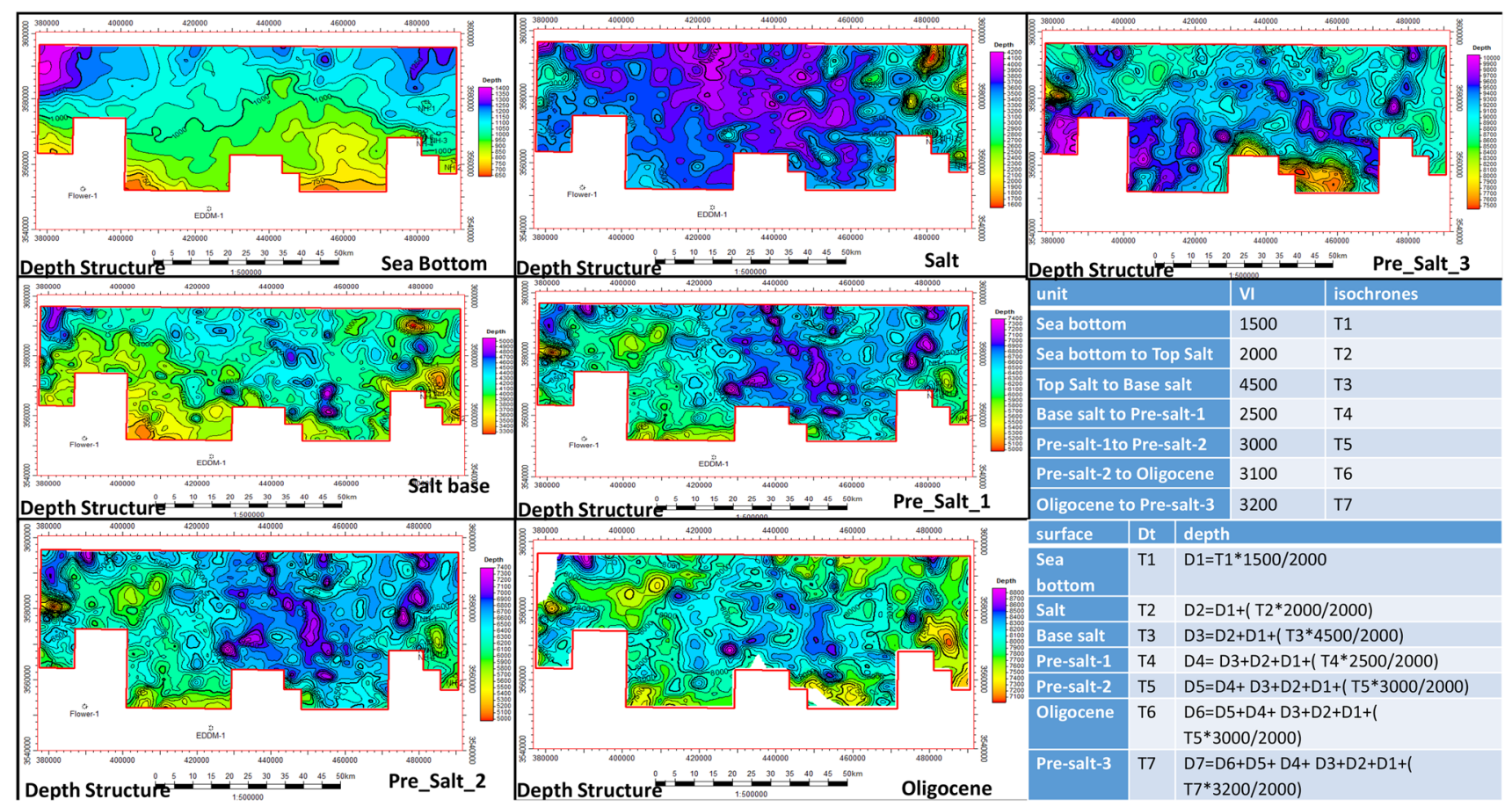

Fig. 14 Depth structure maps using layer cake method

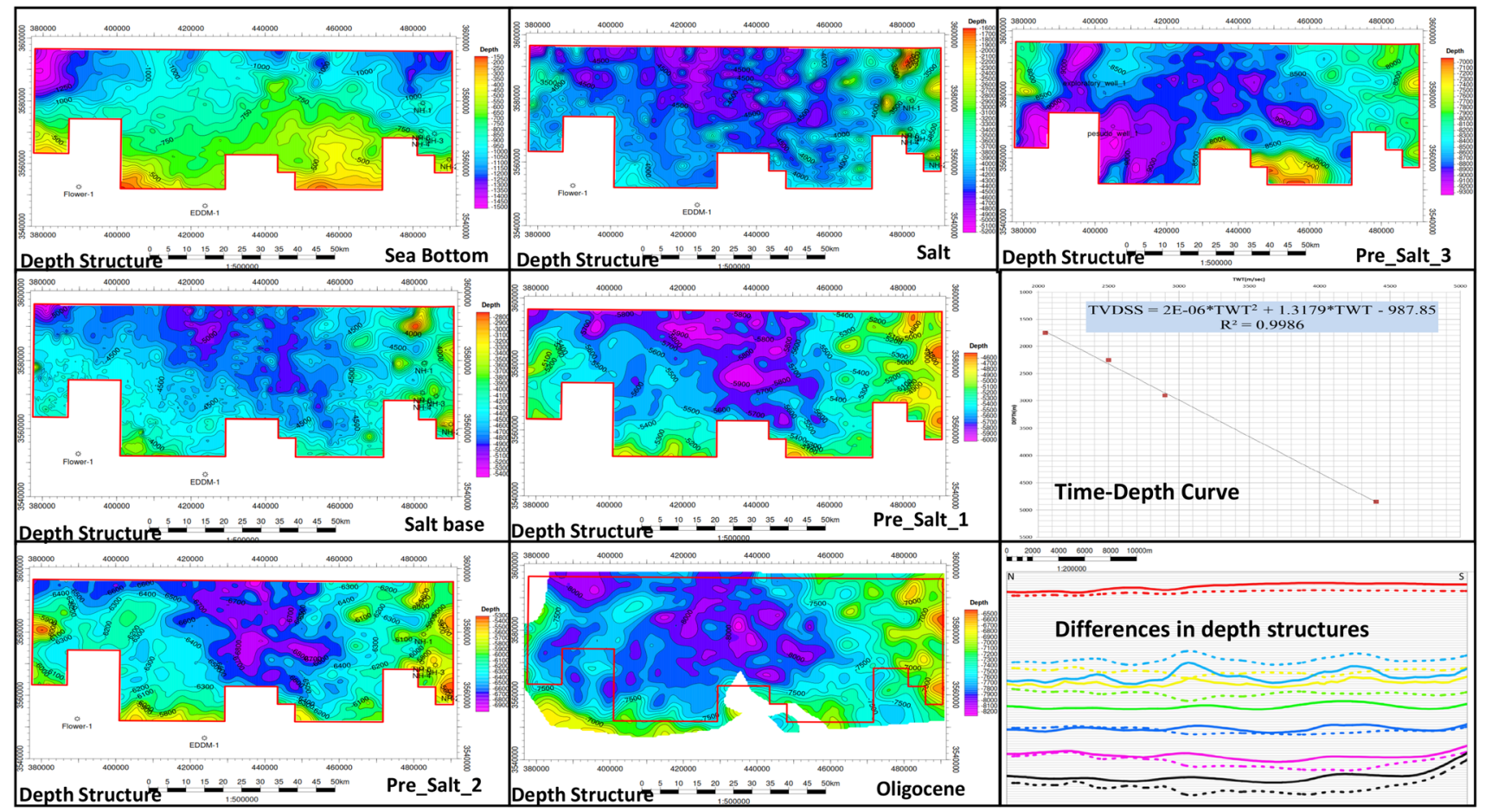

Fig. 15 Depth structure maps using equation method

low-impedance gas sands. Or they could be sands or shales under overpressure. They can be highly cemented sands or coal beds and top of salt diapers or could be due to their formation anisotropy. Because of these reasons, there is still ambiguity in arguing that bright spots are not necessarily all the time hydrocarbon traps. 
(a)

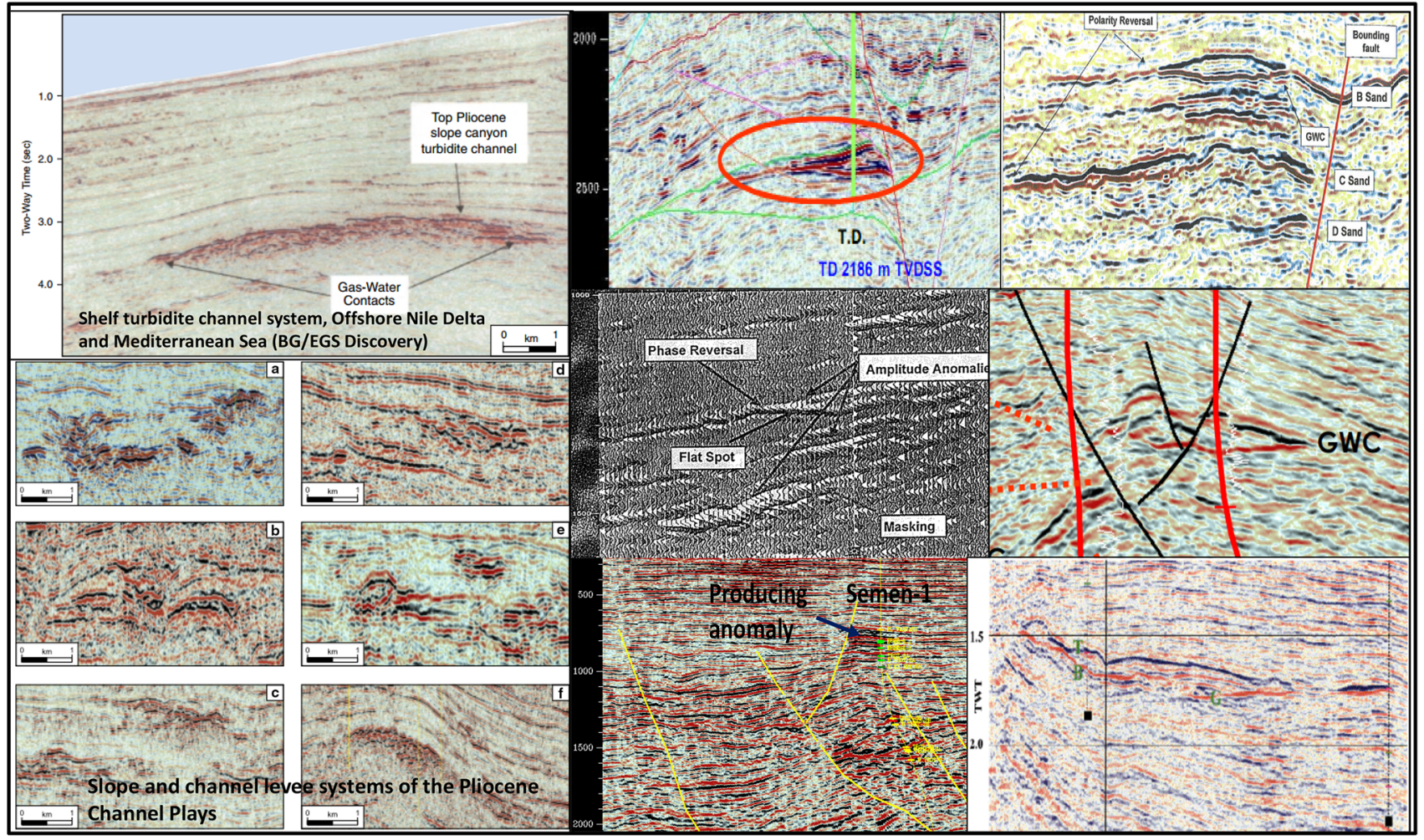

(b)

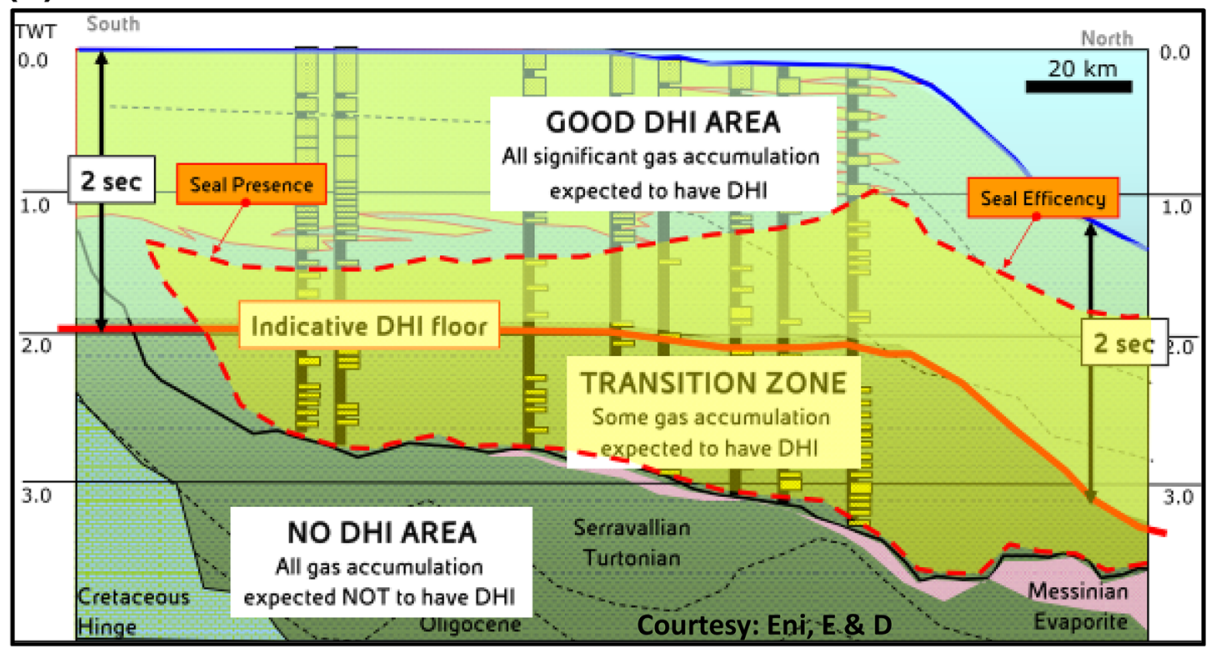

Fig. 16 a Known seismic DHI anomalies from the producing fields around the study area, b DHI anomalies showing on a geological cross section

Tables 2 and 3 describe the documentation of various structure and stratigraphic anomalies interpreted from the existing seismic and drilled-well data sources. These are immensely useful for identifying and interpreting similar anomalies in the study area. In addition, anomalies derived from thickness maps (Fig. 18) are likewise integrated with isochrones and stratigraphy.

\section{Interpretation of seismic structures}

\section{Stages of interpretation}

1. An integrated interpretation is done using the available data. For calibrating the seismic reflections, the drilledwell data from nearby seismic vintages and check- 
Table 2 Observed DHI anomalies of the drilled wells around the study area (Abdel et al. 2001)

\begin{tabular}{|c|c|c|c|c|c|c|c|c|c|c|c|}
\hline $\begin{array}{l}\text { Field } \\
\text { Anomalies }\end{array}$ & Denise & Ha'py & Darffel & Barboni & Fahd & Seman & Nourse & Karouse & Safron & $\begin{array}{l}\text { Gas } \\
\text { Field }\end{array}$ & $\begin{array}{l}\text { Rosetta- } \\
1\end{array}$ \\
\hline Anomaly Amp & Bright & Bright & Bright & Bright & Bright & Bright & Bright & Bright & Bright & Bright & Bright \\
\hline Fiat Spot & Flat & Flat & Flat & Flat & Flat & Flat & Flat & Flat & Flat & Flat & Flat \\
\hline Sag & Sag & Sag & Sag & Sag & Sag & Sag & Sag & Sag & Sag & Sag & Sag \\
\hline $\begin{array}{l}\text { Termination of amplitude against } \\
\text { fault }\end{array}$ & Term & Term & Term & Term & Term & Term & Term & Term & Stra & & Term \\
\hline $\begin{array}{l}\text { Consistency of amplitude and } \\
\text { structure }\end{array}$ & Fit & Fit & Fit & Fit & Fit & Fit & Fit & Fit & Stra & 1700 & Fit \\
\hline $\begin{array}{l}\text { Polarity with respect to ref } \\
\text { horizons }\end{array}$ & Reverse & Reverse & Reverse & Reverse & Reverse & Reverse & Reverse & Reverse & Reverse & Reverse & Reverse \\
\hline Gas chimney & & & & & & & & & Chimney & Chimney & \\
\hline Wavelet shape & Multi & Multi & Multi & Multi & Multi & Multi & Multi & Multi & Multi & Multi & Multi \\
\hline Reservoir amp & Low & Low & Low & Low & Low & Low & Low & Low & Low & Low & Low \\
\hline Reservoir freq & Low & Low & Low & Low & Low & Low & Low & Low & Low & Low & Low \\
\hline Freq below res & Low & Low & Low & Low & Low & Low & Low & Low & Low & Low & Low \\
\hline
\end{tabular}

Table 3 Geological characteristics of the drilled wells around the study area (Abdel et al. 2001)

\begin{tabular}{|c|c|c|c|c|c|c|c|c|c|c|c|}
\hline Field & Denise & Ha'py & Darffel & Barboni & Fahd & Seman & Nourse & Karouse & Safron & $\begin{array}{l}\text { Gas } \\
\text { Field }\end{array}$ & $\begin{array}{l}\text { Rosetta- } \\
1\end{array}$ \\
\hline Reservoir time & Up.mid.plio & Up.plio & Up2up.mid & Up2mid.plio & Up.plio & Up.plio & Up.plio & Up.plio & Channel & Up.plio & Up.plio \\
\hline stratigraphic & Turbidite & Turbidite & Turbidite & Turbidite & Turbidite & Turbidite & Turbidite & Turbidite & Turbidite & Turbidite & Turbidite \\
\hline $\begin{array}{l}\text { Fault within } \\
\text { reservoir }\end{array}$ & Faulted & Faulted & Faulted & Faulted & Faulted & Faulted & Faulted & Faulted & Faulted & Faulted & Faulted \\
\hline $\begin{array}{l}\text { Faults within } \\
\text { reservoir }\end{array}$ & Faults & Faults & Faults & Faults & Faults & Faults & Faults & Faults & Faults & Faults & Faults \\
\hline $\begin{array}{l}\text { Top reservoir } \\
\text { depth }\end{array}$ & 1400 & 1600 & 1000 & 1200 & 2400 & 630 & 650 & 1250 & 2400 & 1700 & 1200 \\
\hline $\begin{array}{r}\text { Thickness to } \\
\text { Messenian }\end{array}$ & 1500 & & 1400 & 1600 & & 1800 & 1800 & 1000 & 1600 & 1500 & \\
\hline
\end{tabular}

shots are taken as control points for interpretation. Horizons selected for interpretation are correlated with all the 2D seismic lines. The authors aim at different seismic attributes (Hanafy et al. 2014) in the nearby 3D seismic area.

2. Structure maps are produced with suitable grid size, smoothening structure contours. While interpreting the seismic data, misties observed between vintages because of varying datum are reconciled and rectified.

3. Utmost care is taken in the promising areas, where there are issues with the quality of data and misties. The potential locations on the computed maps are revisited, confirming the new opportunity areas that fall around the seismic structural closures.

4. Flattening of the seismic data is done to analyze the salt thickness variations and stratigraphic features, especially in the areas where potential opportunities are expected.

\section{Interpretation of horizons}

Figures 13, 14, 15, 16, 17, 18 and 19 describe various structure maps, with interpretation done for evaluating new opportunities in the study area. Stratigraphic features and the interpreted structure anomalies are also included in the integrated interpretation. There is no information from drilled-well data on deeper horizons, since all the wells (existing in the Eastern Mediterranean region) are either shallow or Pliocene drilled wells. Based on the DHI technique, without definition of the shallow layers' zonation and stratigraphic correlation, the nomenclature of the horizons could be problematic and more data are needed to define correctly, substantiating the reasons.

Seven horizons are selected in the current interpretation, and they are described in (a)-(h) sections: 


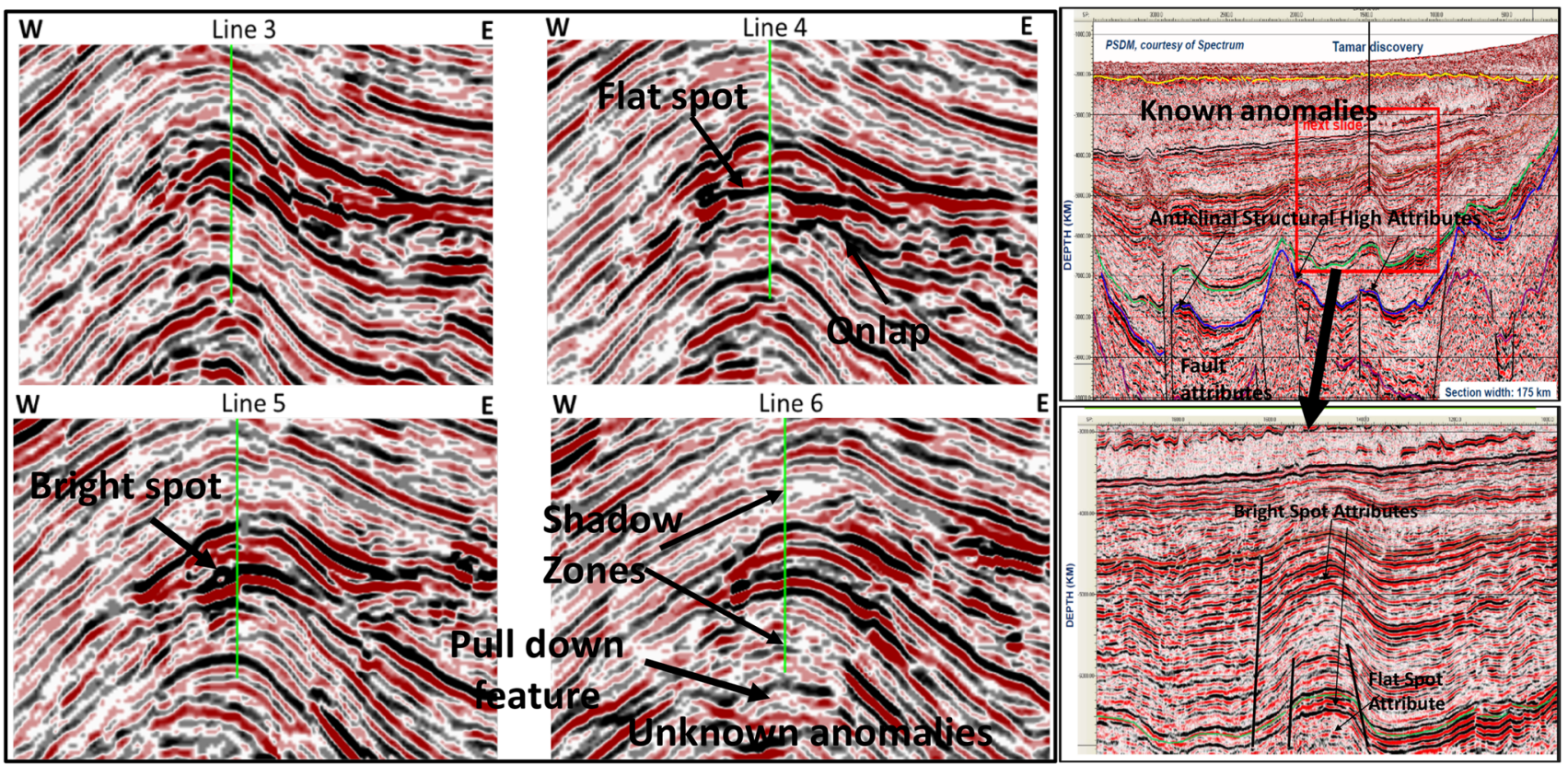

Fig. 17 Known and unknown seismic anomalous features (Hanafy et al. 2014)

\section{(a) Sea bottom}

1. The sea bottom is the key horizon based on which the drilling campaign and prognosis are made. Based on the water depth, the drilling cost is estimated. The indication of the likely cost versus reserves is critical factor in drilling a new opportunity or lead, especially in the deepmarine areas.

2. Secondly, the time-depth conversion is the main factor in estimation of the depth to target. Based on this aspect, certain parameters are calculated such as the pressure gradient, casing, temperature and their associated geological and geophysical parameters. The varying water depth has an effect on these parameters' calculations and their estimations. Mapping of this horizon assists in likely reduction of errors in depth conversions and its dependent parameters.

3. The study of sea bottom structure represents more recent tectonic activity in the study area that allows understanding of the geomorphology of the area and analyze the potential risk related to the exploration activity.

4. The relationship between the recent Nile Delta structure and the stratigraphy of the older ones is inferred.

5. The risk-associated seal analysis is described.

6. The seismic polarity of the horizon is critical in the definition of likely ranking of DHI leads in the study area. (b) Pliocene Structure and Attributes

This is the key horizon (Hanafy et al. 2014) falling in between top- and bottom salt horizons. Many wells penetrated into the Pliocene horizon in the nearby fields have established the commercial oil and gas production (Fig. 19) and to this extent, the attributes generated in the production areas suggest definite clues of reservoir extents and their orientations.

The Pliocene plays are derived by direct hydrocarbon indicator (DHI) techniques and their attributable anomalies as described in Fig. 19. These are based on the integrated interpretation of the data and extraction of the amplitudes within targeted time windows. The anomaly is supported by AVO studies and other post-stack attributes as described in Fig. 19. The following favorable features are associated with potential reservoirs, especially with the Pliocene horizon:

1. A strong seismic amplitude character is an isolated, abruptly dimming feature, but vanishing its character within certain anomaly areas, attributing to shaling out of the reservoir.

2. Flat spot DHI anomaly is interpreted with possible description of gas-water contact areas. The flat spot has a strong peak polarity reversal anomaly.

3. The top of anomaly with strong and continuous trough or negative amplitude character is attributed to be associated with reverse polarity, compared with positive polarity of seismic character connected to the sea bottom horizon. 


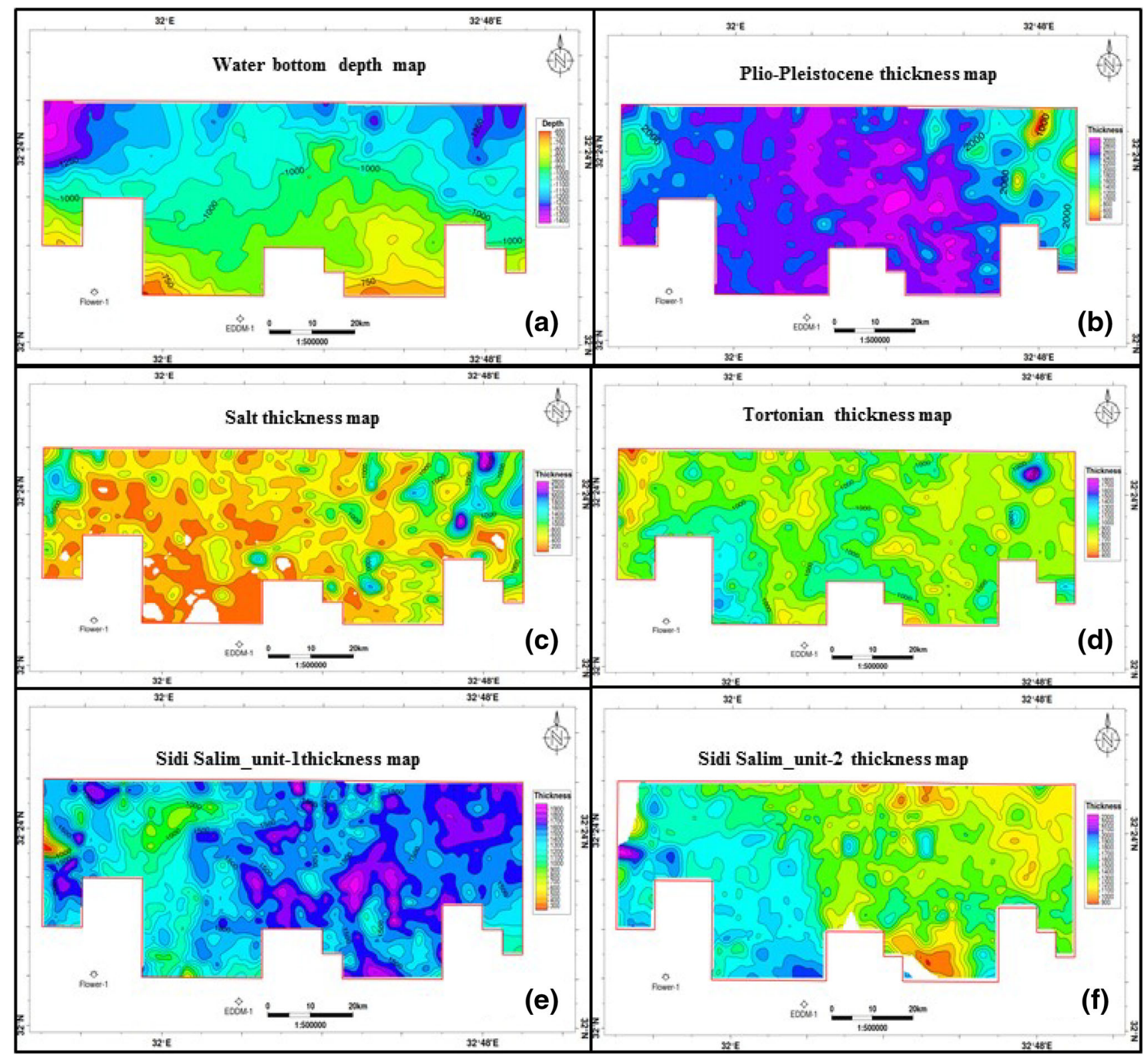

Fig. 18 Thickness maps computed for different targeted layers

4. No sag is observed below the reservoir portion.

5. There is no clear indication of frequency attenuation within the possible reservoir zone areas.

6. Lateral frequency variation, high frequency attenuation below the gas zone and high frequency outside the gas zone are interpreted to have been linked with a shadow zone.

7. The promising reservoir characteristics have relatively lower amplitudes, compared with amplitudes associated with the fluid contacts.

8. Most of the opportunities or leads are associated with peaks of roll-over anticlines that are complemented with growth fault systems.
In addition, all the pseudo-wells proposed within high-water-depth zones $(>1000 \mathrm{~m})$ can add economic values and attract to investors in the study area, keeping in view the size of volumes and prognosis of the proposed wells. In addition, the production facilities and development costs further encourage the investment opportunities in the study area.

(c) Top salt

The salt is vital to geological and geophysical complications and their interpretations. Few of them are: 

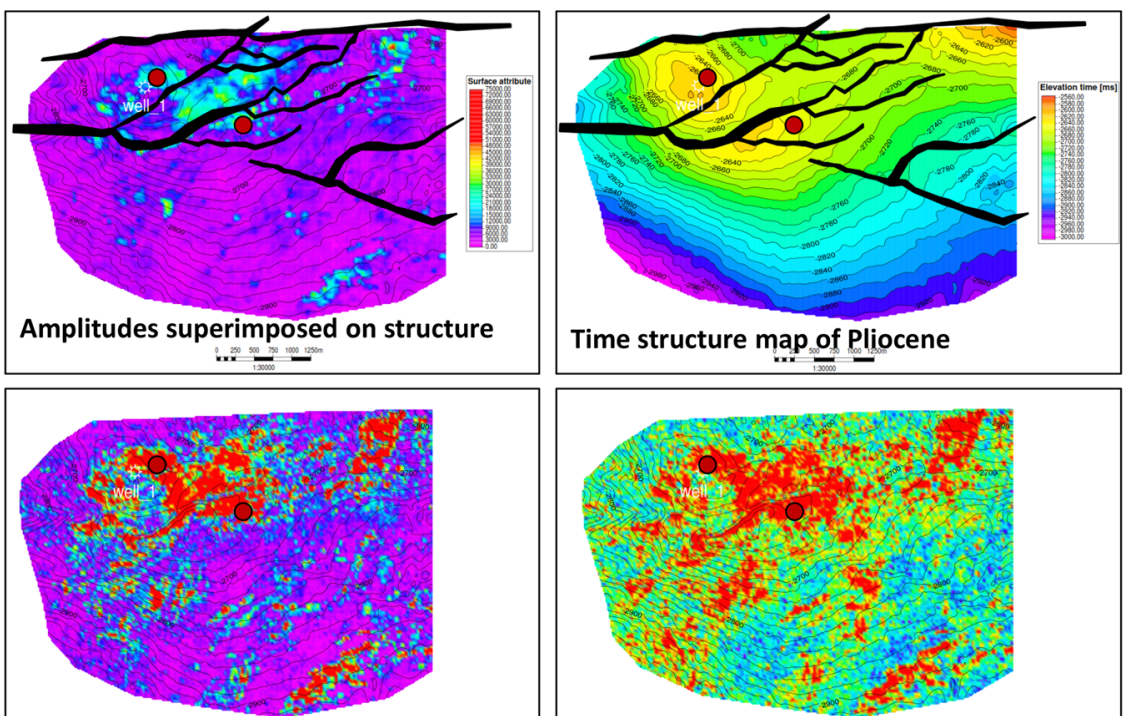

Far-Near AVO attribute on structure incen

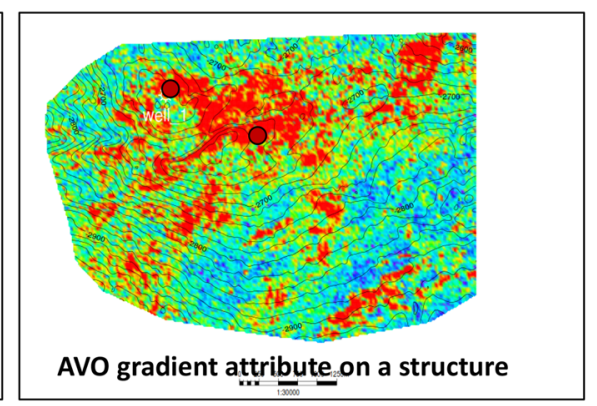

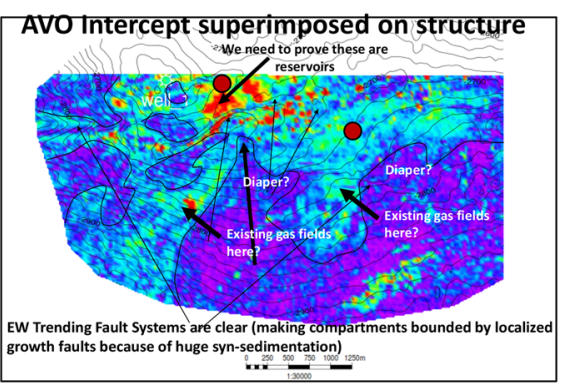

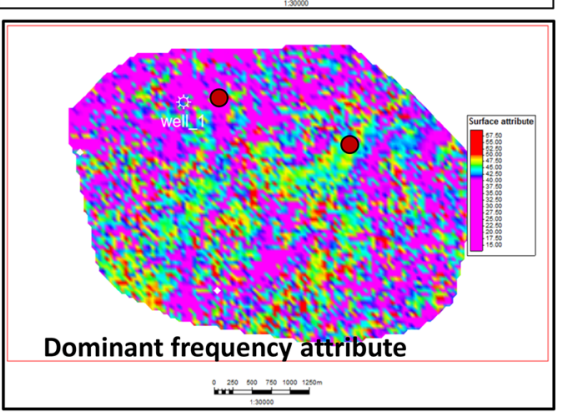

Fig. 19 Seismic attributes superimposed with structure at Pliocene level with pseudo-wells posted

1. The high-geothermal gradient through salt and very low-thermal conductivity are critical factors in assessing the maturity of source rocks in the study area.

2. The high velocity and variable thickness of the salt may have created ambiguous anomalies resulting the depth conversion errors.

3. The velocity anomalies related to salt such as pull-up event could have affected the depth estimations.

4. The likely variation of salt to anhydrite and carbonates is interpreted in many areas in the offshore Nile Delta.

5. The effect of salt motion is interpreted on the structure and geometry of faults and sediment layering.

6. The promising effects of faults cut through, die-out of salt to hydrocarbon migration and type of hydrocarbons especially migration of thermal gas from deep horizons to shallow layers' traps are found in many nearby drilled wells.

7. The characteristic features related to top salt such as growth faults, rollovers and very high rotated blocks are construed.

8. Different types of salt diapirs and their relation to the regional geology are interpreted.

9. The polarity of the seismic horizon is critical in the definition of data polarity and possible ranking of new opportunities and leads associated with the DHI anomalies in the study area.

(d) Bottom salt
1. The bottom salt unit completes the cycle of salt and has the same geological and geophysical importance as that of top salt.

2. The horizon is related to different types of faults that die out very close to the salt.

3. The comparison between the salt top and bottom, in addition to salt thickness, is important factor in depth and possible pull-up effects in the seismic data.

4. The method of depth migration is based on the interpretation of anomalous velocity zones with which this horizon is associated.

(e) Pre-salt-1

1. The horizon has strong trough events representing the first cycle before salt, and they continue all over the study area.

2. There is clear seismic termination of the reflector or what is known as onlap, which means that the reflector has regional unconformity and could be Tortonian-Serravallian marker.

3. There are clear effects of thickness variations and their reductions in the study area.

(f) Pre-salt-2

1. The seismic character associated with the horizon has strong trough representing the second cycle before salt, and it continues all over the study area. 
2. There is clear seismic termination on the reflector or what is known as onlap, which means that the reflector has regional unconformity, which could be intra-Serravallian unconformity marker.

(g) Oligocene

1. The horizon of Oligocene age is chosen after comparing it with nearby published data sources (Barsoum, 1998).

2. The formation represents one of the most potential sources and reservoirs in the Nile Delta offshore basin.

3. The seismic horizon has strong trough representing a regional marker over the study area with nearly constant seismic response character.

4. There is clear high-amplitude and low-frequency layer below this reflector.

5. In the southern and western part of the study area, the reflector is pinched-out against the deepest reflector. In these areas, there are number of strong reflections feasibly representing a submarine fan facies sect.

(h) Pre-salt-3

1. The seismic horizon has strong trough, and it continues all over the study area.

2. There is clear seismic termination on the reflector or what is known as onlap, which means that the reflector has a regional unconformity. The reflector is a clear top of regional structural high extending WNW-ESE, which could be Top Cretaceous or basement reflector. Regionally, there are no data about the Cretaceous WNW-ESE-associated anticlinal structures.

3. There are clear effects of thickness reduction in the upper sequence layers in different areas.

4. The reflector could be associated with top carbonates' marker or Cretaceous unconformity.

\section{Results}

The seismic attributes have provided significant clues of distinct amplitude and frequency characteristics at Pliocene level that could help understand the reservoirs and their distributions in the study area. These reservoir characteristics appear within the periphery of four-way anticlinal structural closures. If these AVO and conventional amplitude attributes have attributed to reservoir characteristics, possibly hydrocarbons may have been trapped within the four-way time structural closures, as interpreted in Figs. 16, 17, 18 and 19. Detailed exploration is recommended in these areas to firm up the positions of the future drillable wells. The authors highlight the following structural features from the interpreted structure maps.

Maximum depth is interpreted toward northeastern and northwestern corners of the map. Trivial water depth anomalies are documented within the area. Salt depth is shallowed toward east and west of the area. Thickness is trivial in the central part, but maximum thickness is observed in the shallower part and eastern part of the study area. Thinning of salt is interpreted in the central block, where new opportunities and leads are identified from deeper horizons. Maximum thickness of Plio-Pleistocene is interpreted, where thickness of salt is minimum, signifying the likely salt migration to eastern and western parts of the study area. The pre-salt structure maps furthermore indicate the following favorable features related to various geological and geophysical characteristics of the block.

1. The pull-up effects related to salt surface variations could be accompanied by over-pressured zones, especially in the surface pre-salt-1. These features are viewed in both thickness and structure maps of pre-salt horizon.

2. Highest thickness of salt diapirs, trending NE-SW and NW-SE is clarified in salt structure maps, and they are located in the NE and NW corners of the study area.

3. Number of variable dimensions are related to four-way dip closures, and the trends of these closures are mainly attributed in the NE-SW and NW-SE directions.

4. Some of these closures are mapped on only one surface, especially in the western part, indicating anomalous responses of these horizons.

5. The salt thickness map does not show anomalous thickness variations on all closures, which means that some of them have geological features related to Oligocene-Miocene sequence of extensional phase.

6. The intensity of data does not allow the interpretation of the expected fault and detailing of structures in the seismic data.

7. The potential ridge or uplift in the southern part has NW-SE trend, which is different from the NE-SW Syrian arc system trend. Particularly, its time equivalent of this event adds a possible result of lower Cretaceous NW-SE-trending rift. This feature causes pinch-out and onlap of Oligocene-Miocene reflector on both sides of the study area and adds likely stratigraphic plays in the deeper targets.

8. The existence of the deep basin in the southwestern part of area is another important feature which adds 
value to the new opportunities and leads in the study area. This basin is associated with OligoceneMiocene setting, which is supposed to be the main hydrocarbon source. This is inferred from the recent discoveries in the eastern Mediterranean basin.

\section{Conclusions}

1. There are clear differences between two methods of depth calculations for all surfaces.

2. The water bottom is deeper in layer cake method than the equation method, implying that the equation velocity is lower than the real one. This rule is not the case with the top salt, where the layer cake is lower than the equation method.

3. The values obtained between two methods are positive in the shallower part and appears to be negative in the deeper part below the salt.

4. The depth-converted layer below the salt is mimicking the salt.

5. The equation methods neglect the effect of anomalous layer, where the layer cake method explains the impact.

6. The depth conversion appears to be effective on the prognosis analysis and prospectivity of the area.

7. The structures computed by equation method of depth conversion appear to be closer to the seismic time structures.

Review of the existing literature and interpretation of the current available exploration data suggest promising structural and combinational traps in the study area. Shelf, slope and deepwater plays along with inverted diapiric saltrelated structures including rotated fault blocks are hydrocarbon plays. Syn-depositional intra-basinal highs are other promising areas of exploration. Mud diapirism and gravitational faulting that affect the structural patterns interpreted in between Rosetta (NE) and Temsah (NW) fault systems contribute to limits of areal extents of pre-salt sequences in the study area. Syn-depositional faults, mobile salt attribute to Pliocene turbiditic and pre-salt systems are potential stratigraphic traps. The other favorable geological features adding values to the new opportunities and leads interpreted in the integrated exploration data of the offshore part of the eastern Mediterranean region are:

1. The structure is associated with Syrian arc system or NE double-plunged anticline as clarified from maps.

2. The structure is a repeated structure from Jurassic to the of base of Pliocene.
3. The amplitude of the structure increases in depth to top Jurassic.

4. The inversion effect continues to the base of the Pliocene, which means that the structure developed after oil migration.

5. The fault effects on thickness variations are clear on both sides of the section, as clarified by growth faults. The reflectors continue their stand in the down thrown block of the reverse fault, indicating the continuous fault effect. This action is repeated from Miocene to Lower Cretaceous package.

6. The half-graben of the Triassic-Jurassic section is clear on the section, which appears not inverted on this section. The inversion fault connects to the middle of the half-graben and Tamar discovery, which could be the critical factor in oil migration, assuming that the possible hydrocarbon source is from Jurassic age.

7. The pay zone that is associated with the Lower Miocene or Qantara (Qhs) has mainly shales of high stand system tract with possible slope fans.

Acknowledgments The authors are thankful to Professor Tariq Alkhalifah, King Abdullah University of Science and Technology, Saudi Arabia, Dr Mohamed Khalifa, University of Zawia, Libya, and Ms Divya Nagarajan, Springer, Chennai, India, for their useful feedback and constructive suggestions. The authors take the opportunity of reviewers' feedback to revisit the manuscript and improvise the entire research article.

Open Access This article is distributed under the terms of the Creative Commons Attribution 4.0 International License (http:// creativecommons.org/licenses/by/4.0/), which permits unrestricted use, distribution, and reproduction in any medium, provided you give appropriate credit to the original author(s) and the source, provide a link to the Creative Commons license, and indicate if changes were made.

\section{References}

Abdel AMH (1999) Seismic stratigraphy and facies architecture of El Manzala area, north eastern desert. 1st international symposium on geophysics, Tanta, Egypt, vol 1, pp 182-194

Abdel A, Lelek JJ (1994) Structural development of the northern Sinai, Egypt and its implication on the hydrocarbon prospectivity of the Mesozoic. GEO 94, the Middle East geosciences conference, Bahrain, vol 1, p 15.30

Abdel A, Day RA, Lelek JJ (1992) Structural evolution and styles of the northern Sinai, Egypt. 11th EGPC exploration and production conference. Egypt 1:546-563

Abdel A, Price RJ, Vaitl JD, Shrallow JA (1994) Tectonic evaluation of the Nile Delta, its impact on sedimentation and hydrocarbon potential, EGPC 12th exploration and production conference, vol 1, pp 19-34

Abdel AA, Shrallow JA, Nada H, Sharaaway O (1996) Geological evaluation of the Nile Delta, Egypt using regal, regional seismic line interpretation, E.G.P.C. 13th Exploration and production conference, vol 1, pp. 224-225 
Abdel A, El Barkooky A, Gerrits M, Meyer HJ, Schwander M, Zaki H (2000a) Tectonic evolution of the Eastern Mediterranean Basin and its significance for hydrocarbon prospectivity in the ultradeep-water of the Nile Delta. The Leading Edge, provo, pp 1086-1102

Abdel AA, El Barkooky A, Gerrits M, Meyer H, Schwander M Zaki, $\mathrm{H}(2000 \mathrm{~b})$ Tectonic evolution of the eastern Mediterranean basin and its significance for hydrocarbon prospectivity of the Nile Delta Ultra-Deep water area, MOC 2000, Alex., Egypt

Argyriadis I, Graciansky PC, Marcoux J, Ricou LE (1980) The opening of the Mesozoic Tethys between Eurasia and ArabiaAfrica. French Bureau de Recherches Géologiques et Minières, Memoir 115:199-214

Ayyad MA, Darwish M (1996) Syrian arc structures: a unifying model of inverted basins and hydrocarbon concurrencies in North Egypt, EGPC 13th exploration and production conference, vol 1, pp 40-59

Barsoum K (2002) Gas chimneys in the Nile Delta slope and gas fields Occurrence, MOC 2002, Alex., Egypt

Barsoum K, Aiolf C, Dalla S, Kamal M (1998) Evaluation and hydrocarbon occurrence in the Plio-Pleistocene succession of the Egyptian Mediterranean Margin. Examples from the Nile Delta basin, 14th exploration and production conference, vol 1, pp 212-221

Bar-Yosef O, Phillips JL (1977) Prehistoric investigations in Gebel Maghara, Northern Sinai. Qedem t. Monographs of the Institute of Archaeology, Hebrew University, Jerusalem

Bernoulli D, Lemoini M (1980) Birth and early evolution of the Tethys: the overall situation. Bur Res Geol Min Mem 115:168-179

Beyth M (1981) Paleozoic vertical movement in Urn Bogma area, southern Sinai. Am Assoc Pet Geol Bull 65:160-165

Biju-Duval BI, Dercourt X, Pichon L (1977) From the Tethys Ocean to the Mediterranean Seas: a plate tectonic model of the evolution of the Western Alpine System: international symposium on the structural history of the Mediterranean Basins: Editions Technip, Paris, pp 143-164

Biju-Duval B, Letouzey J, Mondart L (1979) Variety of margins and deep basins in the Mediterranean. Am Assoc Pet Geol Mem 29:293-317

Cappelleti A, Meda M, Slavi F, Cavozzi C (2010) Structural kinematic evolution of the Northern Nile Delta pre-salt sequences: constraints from 2D restoration and sandbox analogue modeling, MOC 2010, Alex., Egypt

Dobrin MB (1976) Introduction to geophysical prospecting, 4th edn. Mc. Graw. Hill Book Company, New York, p 223

Dolson JO, El-Gendi, Sharmy H, Fathalla M, Gaafar I (1996) Gulf of Suez rift basin sequence models-part A. Miocene sequence stratigraphy and exploration significance in the greater October Field area, Northern Gulf of Suez. In: Youssef M (ed) Proceedings of the 13th petroleum conference, Cairo, Egypt. Egyptian General Petroleum Corporation, pp 227-241

Dolson JC, Steer B, Garing J, Osborne G, Gad A, Amr H (1997) 3D seismic and workstation technology brings technical revolution to the Gulf of Suez Petroleum Company. Lead Edge 16:1809-1817

Dolson JC, Shann MV, Matbouly SI, Hammouda H, Rashed RM (2000a) Egypt in the twenty-first century: petroleum potential in offshore trends, GeoArabia, vol 6, no. 2, 2000, Gulf Petrolink, Bahrain

Dolson JC, Shann MV, Matbouly S, Rashed R, Hammouda H (2000b) The petroleum potential of Egypt. In: Downey MW, Threet JC, Morgan WA (eds) American Association of Petroleum
Geologists Memoir 73. [Also available as an AAPG pre-print CD ROM]

EL Gamal M, Mona A (2010) The driving forces behind the tectonics and evolution of the southern Eastern Mediterranean, with the hydrocarbon systems relationship and after discoveries, MOC 2010, Alex., Egypt

Eyal Y, Reches ZE (1983) Tectonic analysis of the dead sea rift region since the late cretaceous based on mesostructures. Tectonics 2:167-185

Hanafy S, Nimmagadda SL, Mahmoud SE, Hemdan KH (2014) New Insights on interpretation of seismic attributes in the Nile Delta basin for analysing pliocene geological characteristics, MOC 2015, Cairo, Egypt

Harding TP (1985) Seismic characteristics and identification of negative flower structures, positive flower structures and positive structural inversion. Am Assoc Pet Geol Bull 69:458-600

Hemdan K, Barasi M (2002) The Oligocene hydrocarbon potential: a challenging opportunity for the exploratory activity in the Eastern Mediterranean Offshore., Egypt. MOC 2002, Alex, Egypt

Laubscher H, Bernoulli D (1977) Mediterranean and Tethys, In: Ocean Basins and Margins, IV, Mediterranean, A. E. M. Nairn, F. G. Stehli, and W. Kanes, Editors

Laubscher HP, Bernoulli D (1978) Mediterranean and Tethys. In: Nairn AEM (ed) The ocean basins and margins, vol 4A. The Eastern Mediterranean: Plenum Press, New York, pp 1-28

Lowell JD, Genik GJ (1972) Sea-floor spreading and structural evolution of the southern Red Sea. Bull Am Assoc Petrol Geol $56: 247-259$

Magda N (2002) Nile Delta-where is the oil, Egypt, MOC 2002, Alex, Egypt.

Moustafa AR, Khalil MH (1990) Structural characteristics and tectonic evolution of north Sinai fold belts. In: Said R (ed) The geology of Egypt: Rotterdam, Balkema, Chapter 20, pp 381-389

Neev D (1975) Tectonic evolution of the Middle East and the Levantine basin (easternmost Mediterranean). Geology 3:683-686

Neev D (1977) The Pelusium line-a major transcontinental shear. Tectonophysics 38:T1-T8

Neev D, Hall JK, Saul JM (1982) The Pelusium megashear system across Africa and associated lineament swarms. J Geophys Res. doi:10.1029/JB87Ib02P01015

Orwig RO (1982) Tectonic framework of Northern Egypt and the Eastern Mediterranean region, 6th exploration and production conference, vol 1, pp 193-202

Said R (1962) The geology of Egypt. Elsevier Pub, Amsterdam 377 p

Smith AG (1971) Alpine deformation and the oceanic areas of the Tethys, Mediterranean and Atlantic. Geol Soc Am Bull 82:2039-2070

Stets J, Wurster P (1982) Atlas and Atlantic-structural relations. In: von Rad U, Hinz K, Sarnthein M, Seibold E (eds) Geology of the Northwest African continental margin. Springer, Berlin, pp 69-85

Tchalenko JS (1970) Similarities between shear zones of different magnitudes. Geol Soc Am Bull 81:1625-1640

Telford WM, Geldari LP, Sheriff RE (1990) Applied Geophysics, 2nd edn. Cambridge Press University, Cambridge

Wilcox KL, Petrie SA, Maynard LA, Meyer SW (2003) Historical distribution and abundance of Phragmites australis at Long Point, Lake Erie, Ontario. J Great Lakes Res 29:664-680 